\section{Pacific Northwest}

National Laboratory

Operated by Battelle for the

U.S. Department of Energy

\title{
Foaming of E-Glass II (Report for G Plus Project for PPG)
}

\author{
D.-S. Kim \\ M. Portch \\ J. Matyas \\ P. R. Hrma \\ Pacific Northwest National Laboratory \\ L. Pilon \\ University of California, Los Angeles
}

September 2005

Prepared for the U.S. Department of Energy under Contract DE-AC05-76RL01830

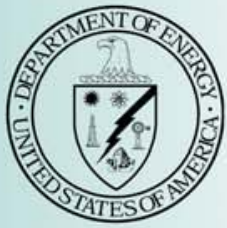




\title{
DISCLAIMER
}

This report was prepared as an account of work sponsored by an agency of the United States Government. Neither the United States Government nor any agency thereof, nor Battelle Memorial Institute, nor any of their employees, makes any warranty, express or implied, or assumes any legal liability or responsibility for the accuracy, completeness, or usefulness of any information, apparatus, product, or process disclosed, or represents that its use would not infringe privately owned rights. Reference herein to any specific commercial product, process, or service by trade name, trademark, manufacturer, or otherwise does not necessarily constitute or imply its endorsement, recommendation, or favoring by the United States Government or any agency thereof, or Battelle Memorial Institute. The views and opinions of authors expressed herein do not necessarily state or reflect those of the United States Government or any agency thereof.

\author{
PACIFIC NORTHWEST NATIONAL LABORATORY \\ operated by \\ BATTELLE \\ for the \\ UNITED STATES DEPARTMENT OF ENERGY \\ under Contract DE-AC05-76RL01830
}

Printed in the United States of America
Available to DOE and DOE contractors from the Office of Scientific and Technical Information,
P.O. Box 62, Oak Ridge, TN 37831-0062;
ph: (865) 576-8401
fax: $(865)$ 576-5728
email: reports@adonis.osti.gov

\begin{abstract}
Available to the public from the National Technical Information Service, U.S. Department of Commerce, 5285 Port Royal Rd., Springfield, VA 22161 ph: (800) 553-6847 fax: $(703) 605-6900$ email: orders@ntis.fedworld.gov online ordering: http://www.ntis.gov/ordering.htm
\end{abstract}

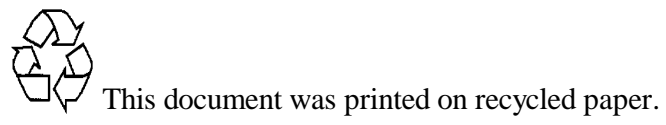




\title{
Foaming of E-Glass II (Report for G Plus Project for PPG)
}

\author{
D.-S. Kim \\ M. Portch \\ J. Matyas \\ P. R. Hrma \\ Pacific Northwest National Laboratory \\ L. Pilon \\ University of California, Los Angeles
}

September 2005

Prepared for the U.S. Department of Energy under Contract DE-AC05-76RL01830

Pacific Northwest National Laboratory

Richland, Washington 99352 


\section{Summary}

In a previous study, the effect of the furnace atmosphere on E-glass foaming was investigated with the specific goal to understand the impact of increased water content on foaming in oxy-fired furnaces. The present study extended the previous study and focused on the effect of glass batch chemical composition on E-glass foaming. The present study also included reruns of foam tests performed in a previous study, which resulted in the same trend: the foaming extent increased nearly linearly with the heating rate and no foam was produced when $\mathrm{CO}_{2}+55 \% \mathrm{H}_{2} \mathrm{O}$ atmosphere was introduced at $300^{\circ} \mathrm{C}$. It was shown that the lack of foaming in the test with $\mathrm{CO}_{2}+55 \% \mathrm{H}_{2} \mathrm{O}$ atmosphere introduced at $300^{\circ} \mathrm{C}$ was caused by a loss of sulfate at $T<1250^{\circ} \mathrm{C}$ because of higher water content at the early stages of melting. The tests with new batches in the present study showed that replacing quicklime with limestone tend to decrease foaming, possibly caused by increased sulfate loss during early stages of melting in the batch with limestone. The batches where $\mathrm{Na}_{2} \mathrm{SO}_{4}$ was replaced with $\mathrm{NaNO}_{3}, \mathrm{NaNO}_{3}+\mathrm{CeO}_{2}$, or $\mathrm{CeO}_{2}$, produced only very limited foaming regardless of the replacing components. As expected, the foaming extent increased as the sulfate content in the batch increased. The results of the present study suggest that foaming can be reduced by

using limestone over quicklime and by decreasing the sulfate addition to a minimum required for refining. 



\section{Contents}

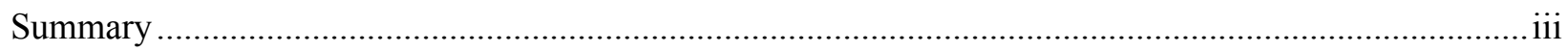

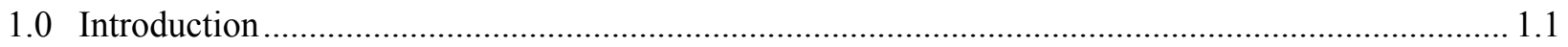

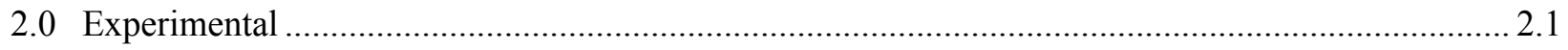

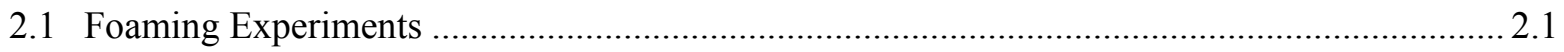

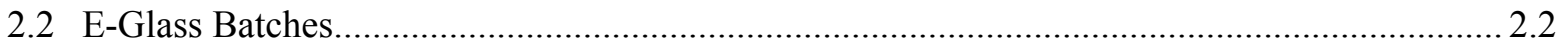

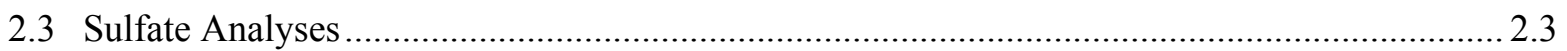

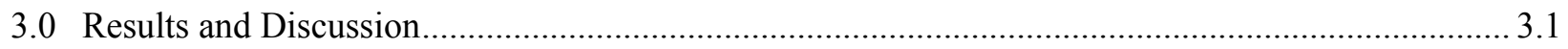

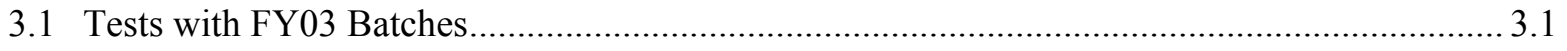

3.2 Sulfur Analyses on FY03 Test Glasses ……................................................................ 3.7

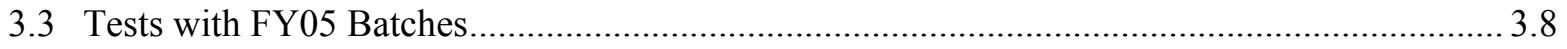

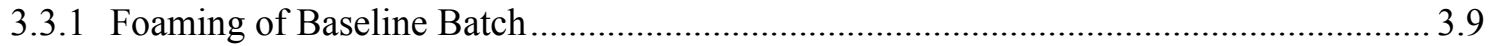

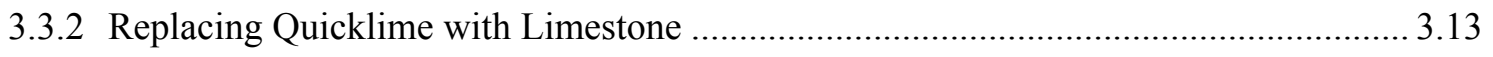

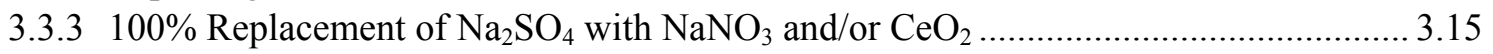

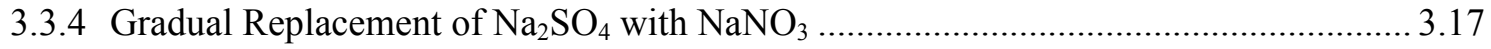

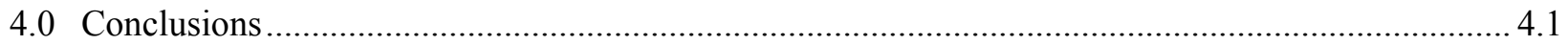

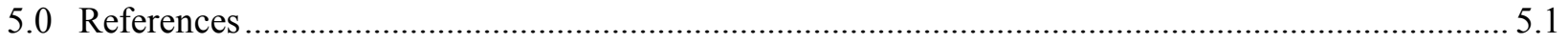




\section{Figures}

Figure 2.1. The Door (a) and the Interior (b) of the Test Furnace with a Silica-Glass Crucible 2.1

Figure 2.2. Schematic of Experimental Set-up for Transient Foam Study Using Controlled Atmosphere

Figure 3.1. Comparison of FY03 Results with FY05 Results Repeated in This Study 3.3

Figure 3.2. Humidity during July 2003 and November 2004

Figure 3.3. $\psi$ Versus Temperature Showing the Effect of Heating Rate on Foaming.....

Figure 3.4. Effect of Heating Rate on the Maximum $\psi$

Figure 3.5. $\psi$ Versus Temperature Showing the Data Points Used to Obtain $\mathrm{d} \psi / \mathrm{d} T$.....

Figure 3.6. $\mathrm{d} \psi / \mathrm{d} T$ Versus Heating Rate 3.6

Figure 3.7. $\psi$ Versus Temperature Showing the Effect of Atmosphere on Foaming

Figure 3.8. $\mathrm{SO}_{3} \mathrm{wt} \%$ in Final Glass Versus Temperature (The trend lines are for visual guidance only) 3.8

Figure 3.9. $\psi$ Versus Temperature for Tests with Baseline FY05 Batch (GPlus05AS) .....

Figure 3.10. $\psi$ Versus Temperature for Tests with the FY03 Batch (Performed in FY05)

Figure 3.11. Foaming Plots to Compare Foaming in FY03 and FY05 Batches under Various Conditions. (a) Ambient, $5{ }^{\circ} \mathrm{C} / \mathrm{min}$; (b) Ambient, $10^{\circ} \mathrm{C} / \mathrm{min}$; (c) Air flow introduced at $1250^{\circ} \mathrm{C}$, $5{ }^{\circ} \mathrm{C} / \mathrm{min}$; and (d) $\mathrm{CO}_{2}+55 \% \mathrm{H}_{2} \mathrm{O}$ introduced at $1250^{\circ} \mathrm{C}, 5^{\circ} \mathrm{C} / \mathrm{min}$

Figure 3.12. $\psi$ Versus Temperature for Tests under Ambient Atmosphere Showing the Different Effect of Heating Rate in FY03 and FY05 Batches

Figure 3.13. $\psi$ Versus Temperature for Tests at $5{ }^{\circ} \mathrm{C} / \mathrm{min}$ Showing the Effect of Atmosphere in FY03 and FY05 Batches

Figure 3.14. $\psi$ Versus Temperature for Tests at $5{ }^{\circ} \mathrm{C} / \mathrm{min}$ under Ambient Atmosphere Showing the Effect of Replacing Quicklime with Limestone

Figure 3.15. $\psi$ Versus Temperature for Tests at $10{ }^{\circ} \mathrm{C} / \mathrm{min}$ under Ambient Atmosphere Showing the Effect of Replacing Quicklime with Limestone

Figure 3.16. $\psi$ Versus Temperature for Baseline and $50 \%$ Limestone Batch Heated at $5{ }^{\circ} \mathrm{C} / \mathrm{min}$ under ambient and $\mathrm{CO}_{2}+55 \% \mathrm{H}_{2} \mathrm{O}$ Atmosphere 
Figure 3.17. $\psi$ Versus Temperature in the Batches with $100 \% \mathrm{Na}_{2} \mathrm{SO}_{4}$ Replaced with $\mathrm{NaNO}_{3}$ Compared with the Baseline Batch

Figure 3.18. $\psi$ Versus Temperature in the Batches with $100 \% \mathrm{Na}_{2} \mathrm{SO}_{4}$ Replaced with $\mathrm{NaNO}_{3}, \mathrm{NaNO}_{3}$ and $\mathrm{CeO}_{2}$, and $\mathrm{CeO}_{2}$ Compared with the Baseline Batch

Figure 3.19. $\psi$ Versus Temperature in the Batches with 0 to $100 \% \mathrm{Na}_{2} \mathrm{SO}_{4}$ Replaced with $\mathrm{NaNO}_{3}$, Tested Under Ambient Atmosphere at $5{ }^{\circ} \mathrm{C} / \mathrm{min}$

Figure 3.20. $\psi$ Versus Temperature in the Batches with 0 to $100 \% \mathrm{Na}_{2} \mathrm{SO}_{4}$ Replaced with $\mathrm{NaNO}_{3}$, Tested under Ambient Atmosphere at $10{ }^{\circ} \mathrm{C} / \mathrm{min}$

Figure 3.21. $\psi$ Versus Temperature in the Batches with 0 to $100 \% \mathrm{Na}_{2} \mathrm{SO}_{4}$ Replaced with $\mathrm{NaNO}_{3}$ Showing the Effect of Heating Rate

Figure 3.22. Maximum $\psi$ Versus Percent Replacement of $\mathrm{Na}_{2} \mathrm{SO}_{4}$ with $\mathrm{NaNO}_{3}$.

Figure 3.23. $\psi$ Versus Temperature Showing the Data Points Used to Obtain $\mathrm{d} \psi / \mathrm{d} T$ for the Tests at (a) $5{ }^{\circ} \mathrm{C} / \mathrm{min}$ and (b) $10{ }^{\circ} \mathrm{C} / \mathrm{min}$

Figure 3.24. $\mathrm{d} \psi / \mathrm{d} T$ Versus Percent Replacement of $\mathrm{Na}_{2} \mathrm{SO}_{4}$ with $\mathrm{NaNO}_{3}$ 3.22

\section{Tables}

Table 2.1. FY05 Batches

Table 3.1. $\mathrm{SO}_{3} \mathrm{wt} \%$ Measured in Glasses after Heating to 1250 or $1500^{\circ} \mathrm{C}$ under Various Atmospheres

Table 3.2. Test Matrix for FY05 Foaming Tests

Table 3.3. Target $\mathrm{SO}_{3}$ Concentration in FY03 and FY05 Batches 


\subsection{Introduction}

Glass foams generated in glass-melting furnaces reduce energy efficiency and can lead to poor glass quality (Hrma and Kim 1994; Kappel et al. 1987; Kim and Hrma 1991 and 1992; Laimböck 1998; Fedorov and Pilon, 2002). Foaming of E-glass refined with sulfate is especially severe when processed with oxy-fuel firing (Laimböck 1998). In a previous study (Kim et al. 2004) performed in FY 2003, the effect of the furnace atmosphere on E-glass foaming was investigated with the specific goal to understand the impact of increased water content on foaming in oxy-fired furnaces. It was shown that humidity in the furnace atmosphere destabilizes foam, while other gases have little effect on foam stability. It was suggested that the higher foaming in oxy-fired furnace compared to air-fired is caused by the effect of water on early sulfate decomposition, promoting more efficient refining gas generation from sulfate, which is known as "dilution effect."

The present FY05 ${ }^{\text {(a) }}$ study extends the previous study and focuses on the effect of glass batch chemical composition on E-glass foaming. It includes foam tests with previous (FY03) batch to investigate the effect of heating rate on foaming and to verify the previously observed effect of atmospheric humidity at early stages of melting on foaming. Different batch compositions were tested in the present study in order to (1) investigate the effect of changing the source of $\mathrm{CaO}$, one of the main E-glass components, and (2) to examine the effect of decreasing the refining agent addition $\left(\mathrm{Na}_{2} \mathrm{SO}_{4}\right)$ and replacing it by $\mathrm{NaNO}_{3}$ used as an oxidation agent to adjust the redox of glass and/or $\mathrm{CeO}_{2}$ used as an alternative refining agent.

(a) This project was funded at the end of FY 2004, and the work was performed during FY 2005. The batches tested in this study will be designated as FY05 batches to distinguish them from those used in a previous study (Kim et al. 2004) performed in FY 2003. 


\subsection{Experimental}

This section describes the experimental procedures and glass batches used for studying E-glass foaming.

\subsection{Foaming Experiments}

The experimental set-up and methods used were described in the previous study (Kim et al. 2004). Briefly, a sample of glass batch placed in a silica-glass cylindrical crucible was heat-treated in the box furnace, shown in Figure 2.1, which was equipped with a silica-glass window in the front door. The sample height-to-width ratio was recorded by a video camera with a long-focus lens. The sample height was determined from the known diameter of the cylindrical crucible. The furnace had a rear recess to provide a darker background for a better contrast at high temperatures.
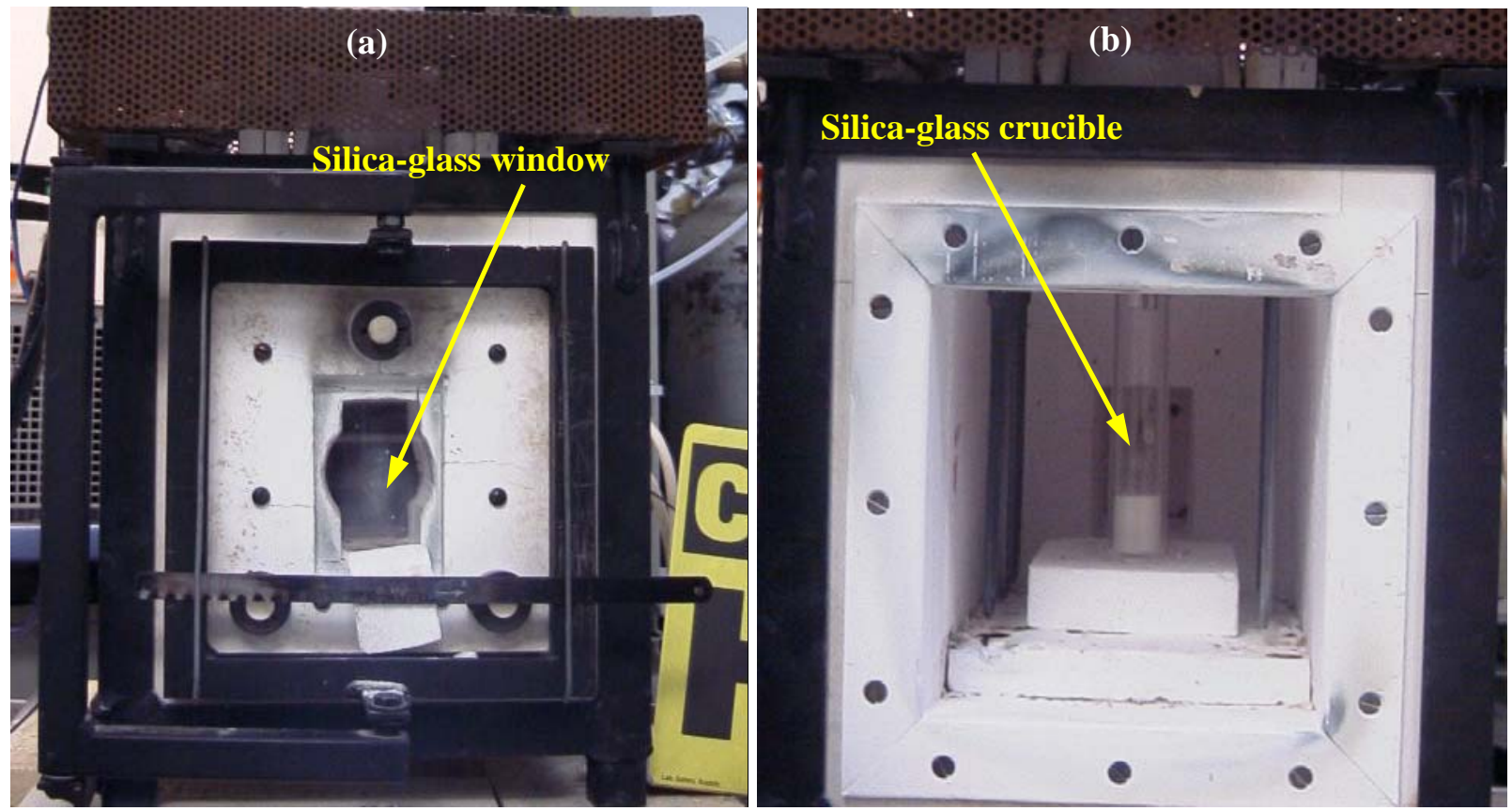

Figure 2.1. The Door (a) and the Interior (b) of the Test Furnace with a Silica-Glass Crucible

For experiments conducted under ambient atmosphere, batches were placed in cylindrical crucibles of 2 $\mathrm{cm}$ inner diameter and $10 \mathrm{~cm}$ high, heated at 5,10 and $15^{\circ} \mathrm{C} / \mathrm{min}$ from $300^{\circ} \mathrm{C}$ to $1500^{\circ} \mathrm{C}$, and kept at $1500^{\circ} \mathrm{C}$ until the foam collapsed. On the other hand, experiments performed under controlled atmosphere were conducted using cylindrical silica-glass crucibles of $2.0 \mathrm{~cm}$ inner diameter and $30 \mathrm{~cm}$ high. Samples were ramp-heated from $300^{\circ} \mathrm{C}$ to $1500^{\circ} \mathrm{C}$ at $5^{\circ} \mathrm{C} / \mathrm{min}$.

Figure 2.2 shows a schematic of the experimental set-up used to control the atmosphere above the sample surface. The batch was initially heated under ambient atmosphere, and gas, such as air or carbon dioxide, was introduced into the crucible when the temperature reached 300 or $1250^{\circ} \mathrm{C}$. The atmosphere gases were introduced at $1250^{\circ} \mathrm{C}$ to minimize the effect of atmosphere on glass melting reactions and thus on foaming so that the effect of atmosphere on foam stability can be investigated (Kim et al. 2004). Humidity was controlled by bubbling compressed gas through water held in a flask kept at a constant 
temperature in a thermostat water bath. The path of the gas from the flask to the crucible was heated via insulated resistive heating coil wrapped around the gas tube to prevent condensation of water in the gas inlet system. The tip of the gas inlet tube was positioned well above the melt surface to minimize its effect on the temperature inside the crucible. For the same reason, the heating coil was turned on in all tests regardless of humidity in the gas mix.

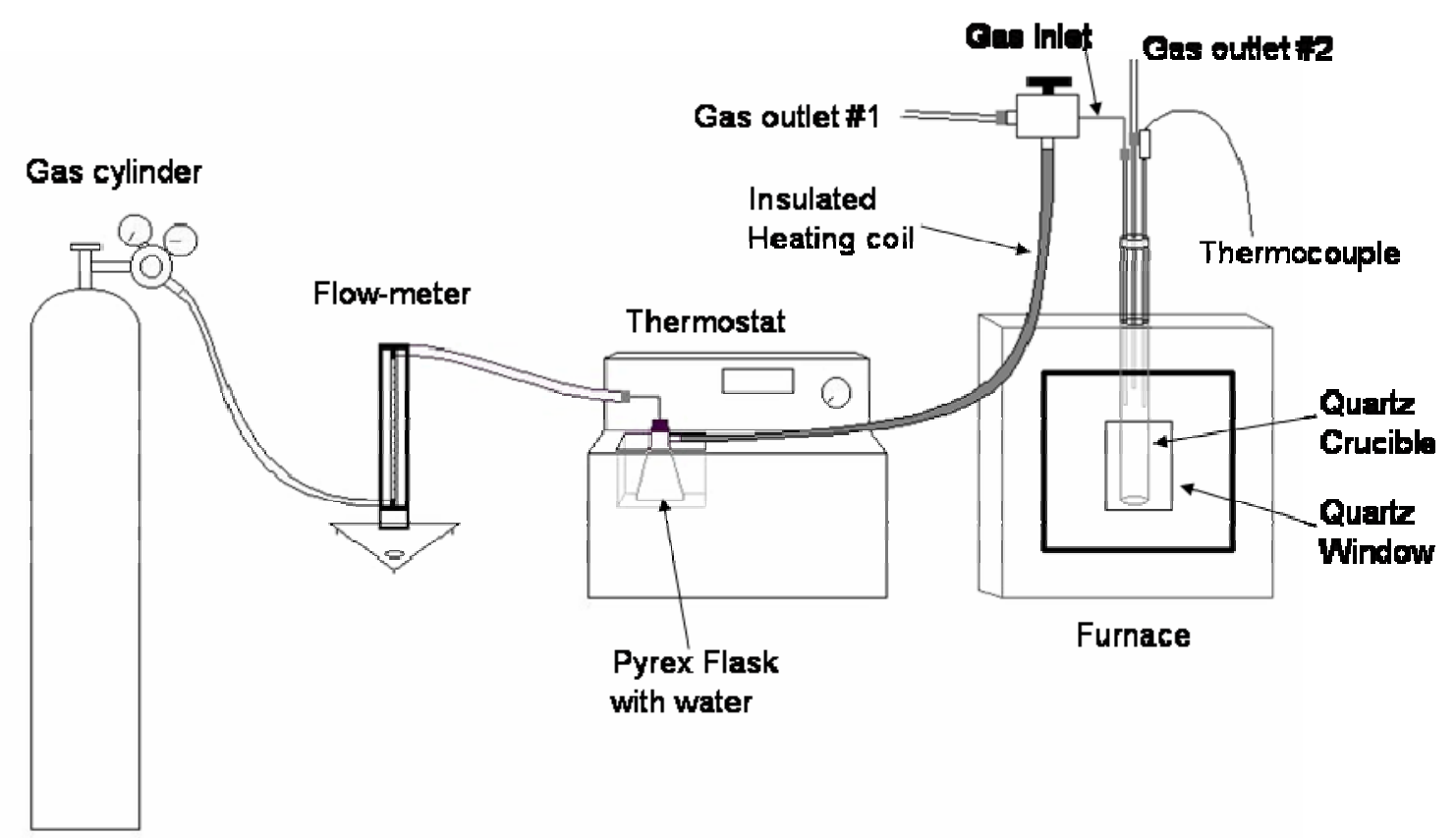

Figure 2.2. Schematic of Experimental Set-up for Transient Foam Study Using Controlled Atmosphere

The gas flow rate was set to $40 \mathrm{~cm}^{3} /$ min for most tests. This rate was deemed low enough to avoid mechanical agitation of the foam and a decrease of the temperature above the melt while maintaining a constant atmosphere composition. At this flow rate, the gas content in the crucible would be renewed roughly every $2 \mathrm{~min}$. The volumetric flow rate of gas was measured before the gases were humidified; thus, the actual flow rate was higher for atmospheres containing $\mathrm{H}_{2} \mathrm{O}$.

\subsection{E-Glass Batches}

To test the effect of the rate of heating on E-glass foaming and to confirm the effect of humidity introduced at early stages of melting, several experiments performed in the previous study (Kim et al. 2004) were repeated in the present study using the same E-glass batch (FY03 batch) that was received from PPG and contained all the raw materials in prescribed proportions except for $\mathrm{Na}_{2} \mathrm{SO}_{4}$. Batches were mixed with $0.14 \mathrm{wt} \% \mathrm{Na}_{2} \mathrm{SO}_{4}$, which results in $0.17 \mathrm{wt} \% \mathrm{SO}_{3}$ in glass, including the sulfate introduced as impurity from other raw materials (roughly half of the total sulfate came from $\mathrm{Na}_{2} \mathrm{SO}_{4}$ ). All the tests with FY03 batches were done with $4 \mathrm{~g}$ of batch.

Table 2.1 summarizes the current FY05 batches that were also supplied from PPG premixed. The FY05 batches were formulated aimed at (1) investigating the effect of changing the source of $\mathrm{CaO}$ (GPlus05B 
and $\mathrm{C}$ ) and (2) examining the effect of decreasing the refining agent $\left(\mathrm{Na}_{2} \mathrm{SO}_{4}\right)$ replaced by $\mathrm{NaNO}_{3}$ and/or $\mathrm{CeO}_{2}$ (GPlus05D, E, and F). The $\mathrm{NaNO}_{3}$ is added to adjust the redox of glass and $\mathrm{CeO}_{2}$ is used as an alternative refining agent. The sulfate addition was higher in FY05 baseline batch, corresponding to 0.25 $\mathrm{wt} \% \mathrm{SO}_{3}$ in glass, of which $0.22 \mathrm{wt} \% \mathrm{SO}_{3}$ came from $\mathrm{Na}_{2} \mathrm{SO}_{4}$ and the rest was introduced as impurity from other raw materials (accordingly, the batches without sulfate addition, GPlus05D, E, and F, had a target $\mathrm{SO}_{3}$ concentration of $0.03 \mathrm{wt} \%$ ). The $\mathrm{FY} 03$ batch did not contain $\mathrm{NaNO}_{3}$ or $\mathrm{CeO}_{2}$ although the sulfate addition was lower than FY05 baseline batch.

The initial tests with FY05 batches, except for GPlus05B and C, were conducted initially with $4 \mathrm{~g}$ of batch. This amount was later decreased to $3.5 \mathrm{~g}$ to keep foaming within the observable range of the experimental setup. The size of GPlus05B and $\mathrm{C}$ batches was adjusted to produce the same mass of glass as the baseline; the melt-to-batch mass ratios are given in Table 2.1 .

Table 2.1. FY05 Batches

\begin{tabular}{||l|l|c||}
\hline \hline Batch ID & \multicolumn{1}{|c||}{ Description } & $\begin{array}{c}\text { Melt-to-Batch } \\
\text { Mass Ratio }\end{array}$ \\
\hline GPlus05A & Baseline & 0.914 \\
\hline GPlus05B & $50 \%$ replacement of quicklime by limestone & 0.863 \\
\hline GPlus05C & $100 \%$ replacement of quicklime by limestone & 0.801 \\
\hline GPlus05D & $100 \%$ replacement of $\mathrm{Na}_{2} \mathrm{SO}_{4}$ by $\mathrm{NaNO}_{3}$ & 0.915 \\
\hline GPlus05E & $100 \%$ replacement of $\mathrm{Na}_{2} \mathrm{SO}_{4}$ by $\mathrm{NaNO}_{3}$ with $0.25 \mathrm{wt} \% \mathrm{CeO}_{2}$ & 0.915 \\
\hline GPlus05F & $100 \%$ replacement of $\mathrm{Na}_{2} \mathrm{SO}_{4}$ by $0.25 \mathrm{wt} \% \mathrm{CeO}_{2}$ & 0.916 \\
\hline
\end{tabular}

\subsection{Sulfate Analyses}

To check the hypothesis regarding the reason for the lack of foaming in the test with $\mathrm{CO}_{2}+55 \% \mathrm{H}_{2} \mathrm{O}$ introduced at $300^{\circ} \mathrm{C}$ and to better understand the dilution effect in E-glass foaming, discussed in our previous study (Kim et al. 2004), selected glasses from foaming experiments were analyzed for sulfate concentration. Two additional experiments were performed with $\mathrm{FY} 03$ batch to produce glasses for $\mathrm{SO}_{3}$ concentration measurement: the batch was heated at $5{ }^{\circ} \mathrm{C} / \mathrm{min}$ one under ambient atmosphere and the other under $45 \% \mathrm{CO}_{2}+55 \% \mathrm{H}_{2} \mathrm{O}$ atmosphere. Both melts were air quenched once the temperature reached $1250^{\circ} \mathrm{C}$. Sulfur concentration was determined in the quenched glass samples by inductively coupled plasma-atomic emission spectrometry after digesting the glass with a mixture of concentrated nitric, perchloric, hydrofluoric, and hydrochloric acids. 


\subsection{Results and Discussion}

The foaming test results are given in the form of gas phase-to-liquid phase volume ratio, $\psi$, defined as

$$
\psi=\frac{V_{g}}{V_{m}}
$$

where $V_{\mathrm{g}}$ is the volume of gas in the sample, and $V_{\mathrm{m}}$ is the volume of melt in the sample. Obviously, $V_{\mathrm{g}}=V-V_{\mathrm{m}}$, where $V$ is the total volume of the foam. Since the sample was contained in a vertical cylindrical column of constant cross-sectional area,

$$
\psi=\frac{H}{H_{m}}-1
$$

where $H$ is the sample height, and $H_{\mathrm{m}}$ is the height of the gas free sample. The height $H$ is measured from the video recording whereas $H_{\mathrm{m}}$ is calculated using the formula,

$$
H_{m}=\frac{m_{b} f_{b}}{A \rho_{m}}
$$

where $m_{b}$ is the mass of the batch loaded into the crucible, $f_{b}$ is the melt-to-batch mass ratio, A is the crucible inner cross-section area, and $\rho_{m}$ is the final melt density.

For the glass in the previous study (Kim et al. 2004), $f_{b}=0.899, \rho_{m}=2.45 \mathrm{~g} / \mathrm{mL}$ (estimated at $1350^{\circ} \mathrm{C}$ ), $A$ $=\pi r_{\mathrm{c}}^{2}$, where $r_{\mathrm{c}}=10 \mathrm{~mm}$ is the crucible inner radius, and $m_{b}=4.00 \mathrm{~g}$ for all experiments. Hence,

$$
H_{m}=4.67 \mathrm{~mm}
$$

However, the present study used the batches with various $f_{b}$ and $m_{b}$. In the previous study (Kim et al. 2004) the inner radius $r_{\mathrm{c}}$ was assumed to be a constant at $10 \mathrm{~mm}$ for all the crucibles, whereas the $r_{\mathrm{c}}$ was measured for each crucible in the present study. The values of $H_{\mathrm{m}}$ varied between 4.53 and $4.78 \mathrm{~mm}$.

\subsection{Tests with FY03 Batches}

Six tests were conducted in the present study using the FY03 batch; five of which were the duplicates of the FY03 tests (Kim et al. 2004). The six tests with the FY03 batch aimed at:

- Investigating the effect of heating rate on foaming. Three tests were conducted under ambient atmosphere heated at 5,10 , and $15^{\circ} \mathrm{C} / \mathrm{min}$ and kept at $1500^{\circ} \mathrm{C}$ for $30 \mathrm{~min}$ (the tests at 5 and $10{ }^{\circ} \mathrm{C} /$ min repeated FY03 tests).

- Verifying the previously observed effect of atmospheric humidity at early stages of melting on foaming. Two tests were conducted under controlled atmospheres with the gas introduced at $1250^{\circ} \mathrm{C}$, one under dry air and the other under $\mathrm{CO}_{2}+55 \% \mathrm{H}_{2} \mathrm{O}$ (re-runs of Tests 1 and 8 reported in 
$\mathrm{Kim}$ et al. 2004). One test was conducted under $\mathrm{CO}_{2}+55 \% \mathrm{H}_{2} \mathrm{O}$ atmosphere with the gas introduced at $300^{\circ} \mathrm{C}$ (re-run of Test 13 reported in $\mathrm{Kim}$ et al. 2004). In all cases, the rate of heating was $5^{\circ} \mathrm{C} / \mathrm{min}$.

Figure 3.1 compares the FY03 results with the results from the FY05 study. For each plot, "FY03 result" is as reported in Kim et al. 2004, "FY03 Test Re-evaluated in FY05" is the result of the re-evaluation using the video recordings from FY03 study, and the "FY05 result" is the result of FY05 tests performed with the same FY03 batch. Surprisingly, the extent of foaming was substantially lower in the current experiments than in those reported by Kim et al. (2004). Comparable results were obtained only in the test under $\mathrm{CO}_{2}+55 \% \mathrm{H}_{2} \mathrm{O}$ atmosphere with the gas introduced at $300^{\circ} \mathrm{C}$ that did not produce foam.

Several causes were considered to explain the consistently observed lower level of foaming in repeated experiments. Batching error (addition of $\mathrm{Na}_{2} \mathrm{SO}_{4}$ to the premixed batch of all other raw material) was deemed unlikely after reviewing the test records. The re-evaluation of Kim et al. (2004) test data to check whether the difference was caused by the difference in the measurement method revealed a noticeable difference in calculating the $\psi$ value caused by the difference in obtaining $r_{\mathrm{c}}$ values. It was assumed in Kim et al. (2004) that $r_{\mathrm{c}}=10 \mathrm{~mm}$. Figure 3.1 shows that with corrected data, based on estimated $r_{\mathrm{c}}$ values (not measured in previous tests in FY03), the difference between previous and present results is decreased, but does not disappear. Another possible explanation is the effect of the lab atmosphere humidity. Indeed, the humidity during the early stage of melting below $1250^{\circ} \mathrm{C}$ has a strong effect on the sulfate decomposition and foaming (see Section 3.2). The previous testing was conducted in July, 2003, the present testing in November, 2004. Figure 3.2 compares the absolute humidity over 30 days in each month. The absolute humidity, $\omega$, was obtained using the equation

$$
\omega=\frac{0.622 \phi P_{g}}{P-\phi P_{g}}
$$

where $P_{\mathrm{g}}$ is the saturation pressure of water at the average temperature, $P$ is the atmospheric pressure, and $\phi$ is the relative humidity which was obtained from internet ${ }^{(a)}$. Although there were a few spikes when the humidity during November was higher than that of July, the overall difference was only $0.002 \mathrm{~kg}$ $\mathrm{H}_{2} \mathrm{O} / \mathrm{kg}$ air in monthly averages. Thus, it is unlikely that the difference in foaming was caused by the difference in air humidity. There is a possibility that the change of batch humidity with time during storage has an effect, which was not verified in the present study. Because of this difference between FY03 and FY05 data with the same batch, it was not attempted to consolidate the results of FY03 and FY05 tests for general discussion.

Though the consistent difference between the previous and present data remains unclear, both studies show the same trend that glass foaming increases with increasing rate of heating, as discussed below, and agree that no foam is produced when $\mathrm{CO}_{2}+55 \% \mathrm{H}_{2} \mathrm{O}$ atmosphere is introduced at $300^{\circ} \mathrm{C}$ (Figure 3.1e).

(a) http://www.wunderground.com/. 

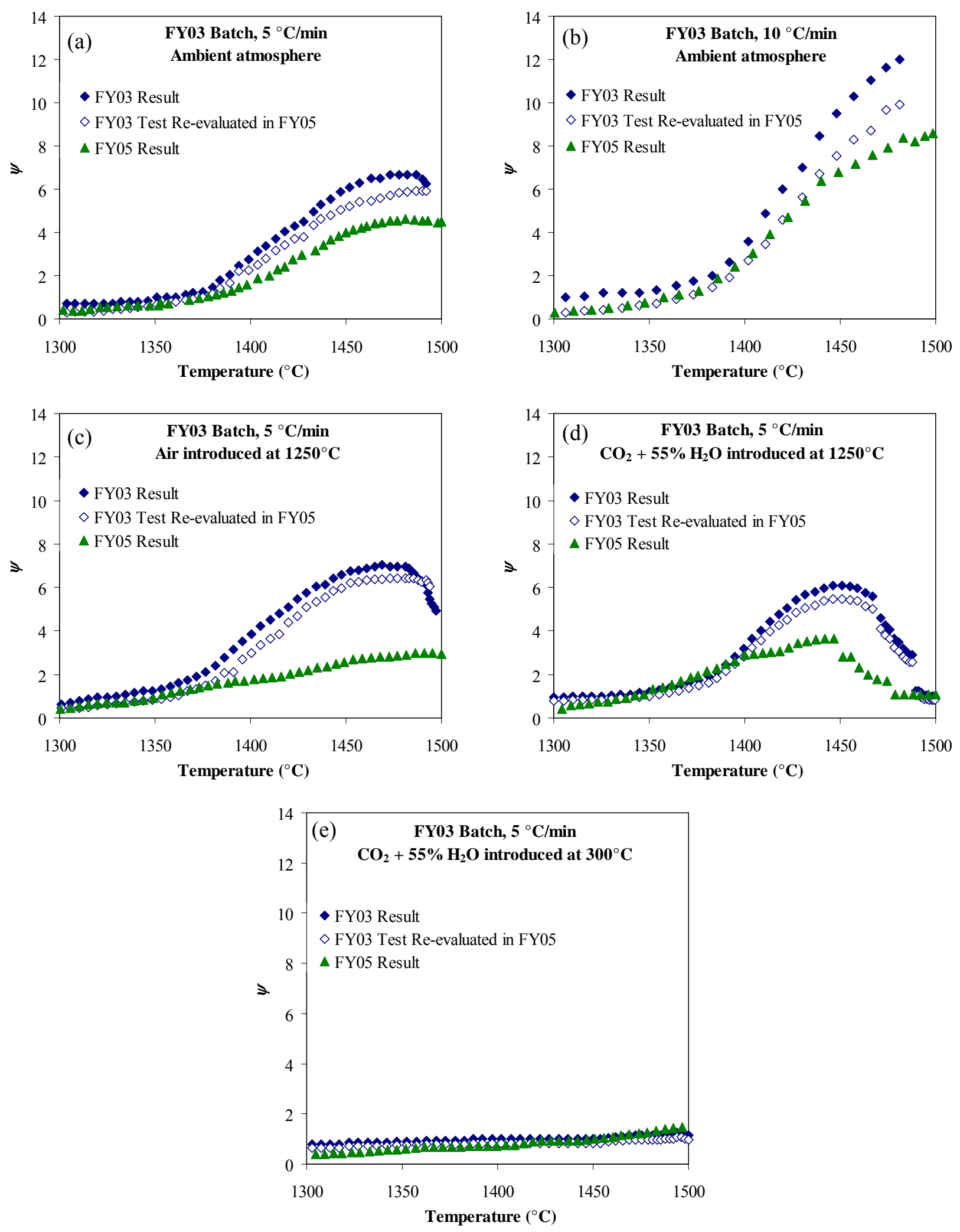

Figure 3.1. Comparison of FY03 Results with FY05 Results Repeated in This Study 


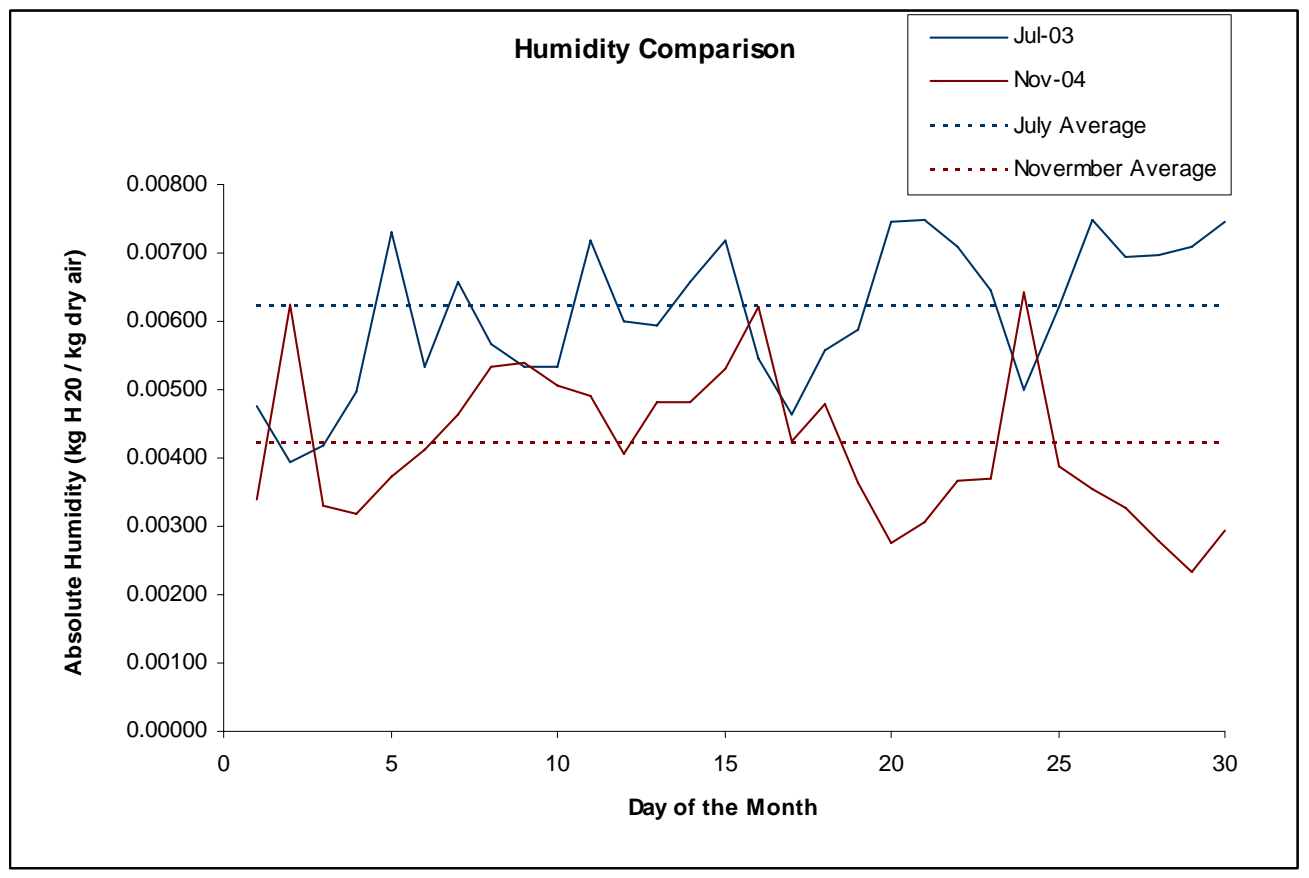

Figure 3.2. Humidity during July 2003 and November 2004

Figure 3.3 shows the $\psi$ as a function of temperature for the FY03 batch tested in FY05 at three different heating rates. Figure 3.4 shows the maximum $\psi$ as a function of heating rate. Figure 3.5 shows the data points on the linear portion of the foaming curve used to obtain the $\mathrm{d} \psi / \mathrm{d} T$ and Figure 3.6 shows the $\mathrm{d} \psi / \mathrm{d} T$ as a function of heating rate. Both the maximum $\psi$ and $\mathrm{d} \psi / \mathrm{d} T$ increased nearly linearly with the heating rate.

Figure 3.7 shows the $\psi$ as a function of temperature for the FY03 batch tested in FY03 and FY05 at three different atmospheres: ambient, air introduced at $1250^{\circ} \mathrm{C}$, and $\mathrm{CO}_{2}+55 \% \mathrm{H}_{2} \mathrm{O}$ introduced at $1250^{\circ} \mathrm{C}$. The FY05 results confirm the trend found previously, namely, that the atmosphere had no noticeable effect on the maximum $\psi$ within the experimental uncertainty and $\mathrm{CO}_{2}+55 \% \mathrm{H}_{2} \mathrm{O}$ atmosphere introduced at $1250^{\circ} \mathrm{C}$ caused the foam to collapse earlier. For the tests under ambient and under air introduced at $1250^{\circ} \mathrm{C}$, the $\mathrm{FY} 03$ results showed distinct peaks at about $1470^{\circ} \mathrm{C}$ whereas $\mathrm{FY} 05$ results did not. The reason for this difference is not clear. 


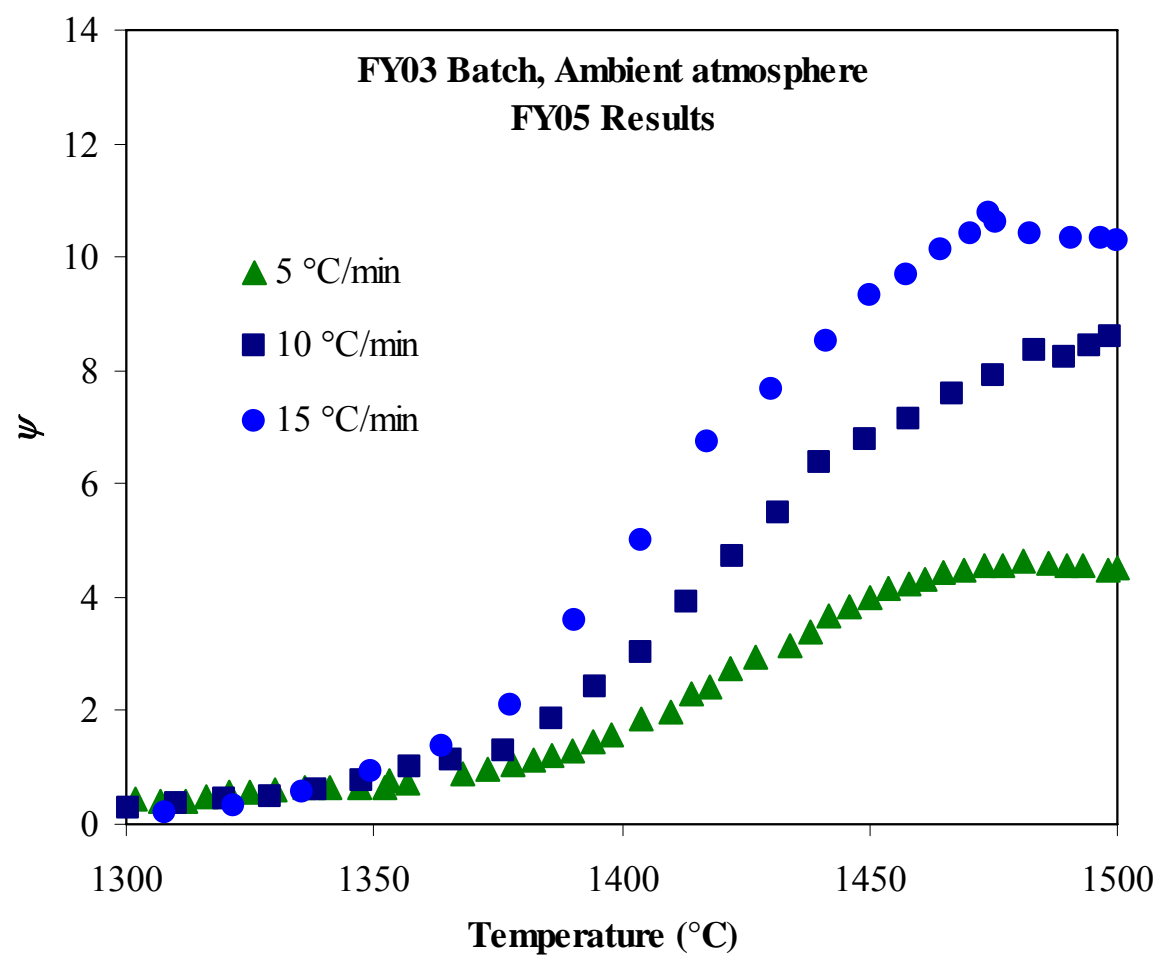

Figure 3.3. $\psi$ Versus Temperature Showing the Effect of Heating Rate on Foaming

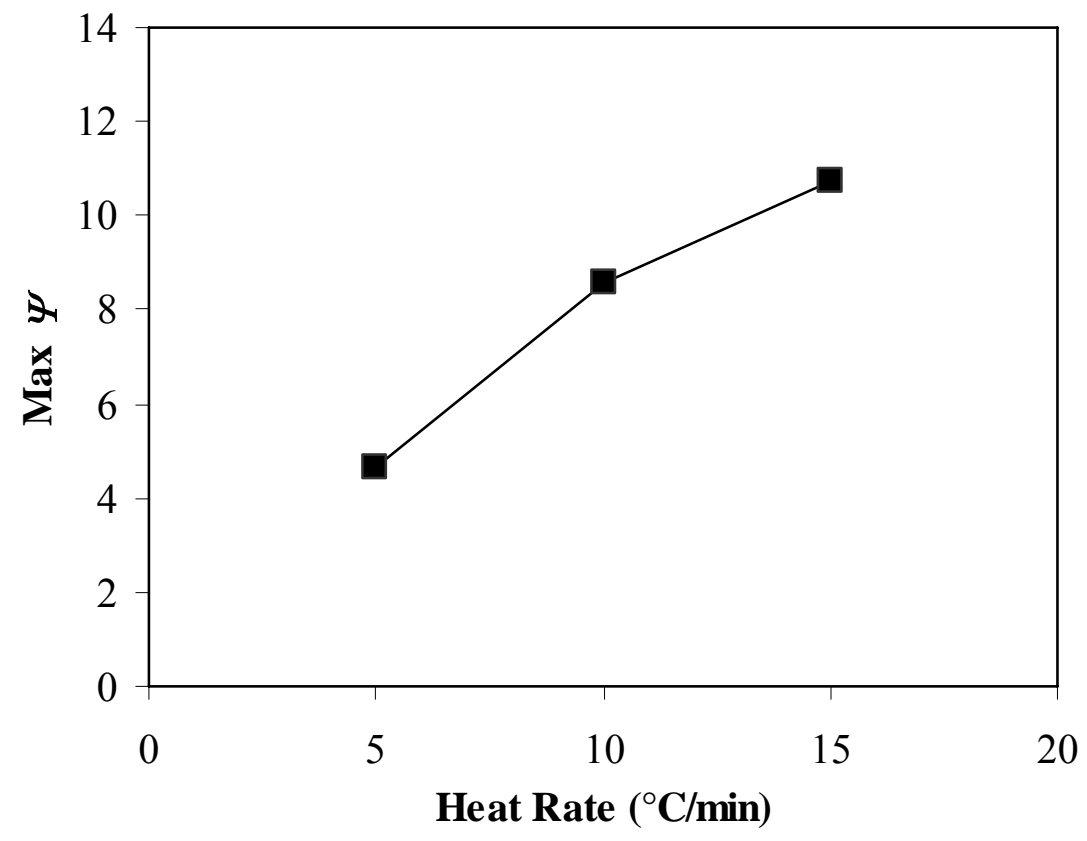

Figure 3.4. Effect of Heating Rate on the Maximum $\psi$ 


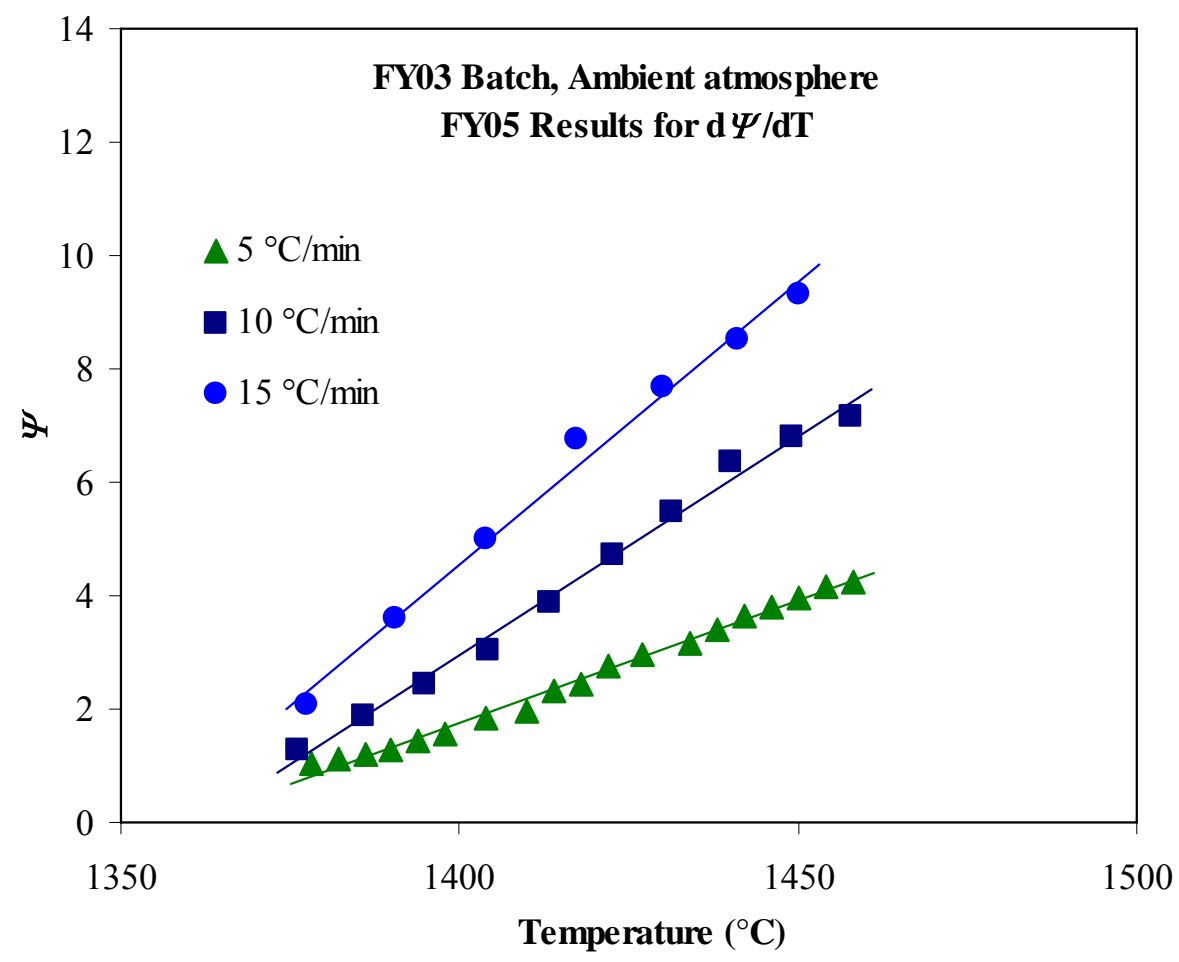

Figure 3.5. $\psi$ Versus Temperature Showing the Data Points Used to Obtain $\mathrm{d} \psi / \mathrm{d} T$

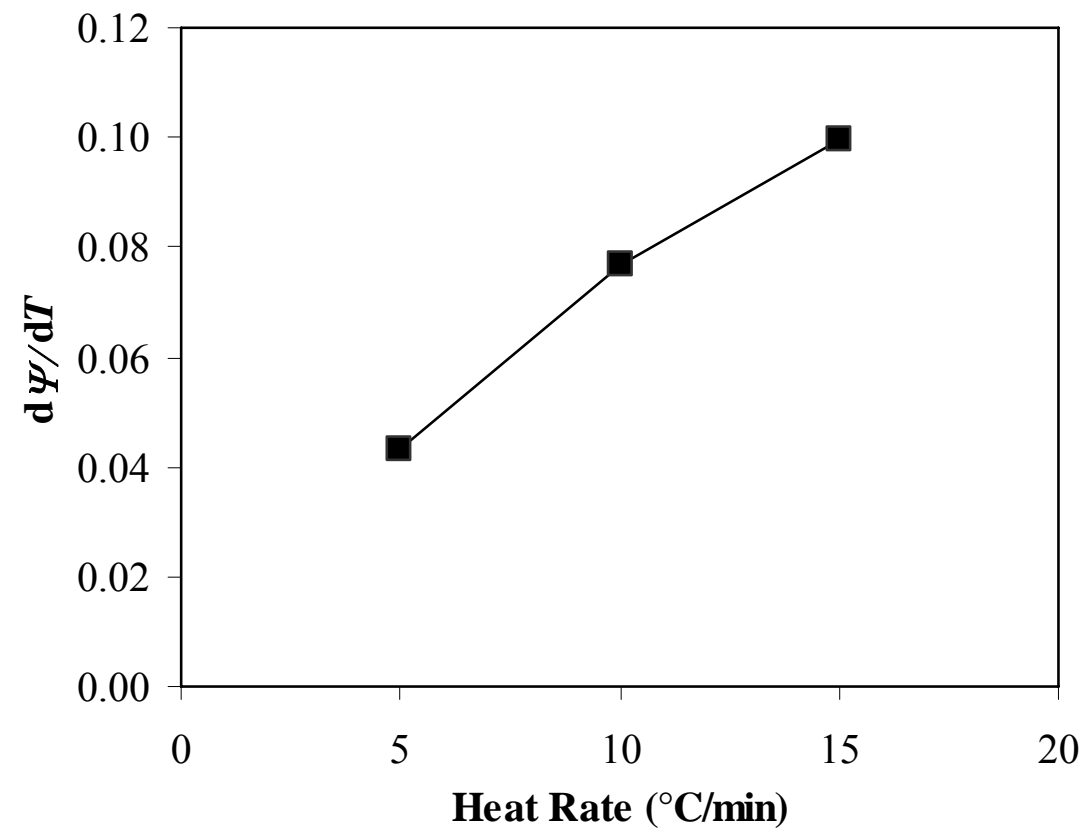

Figure 3.6. $\mathrm{d} \psi / \mathrm{d} T$ Versus Heating Rate 


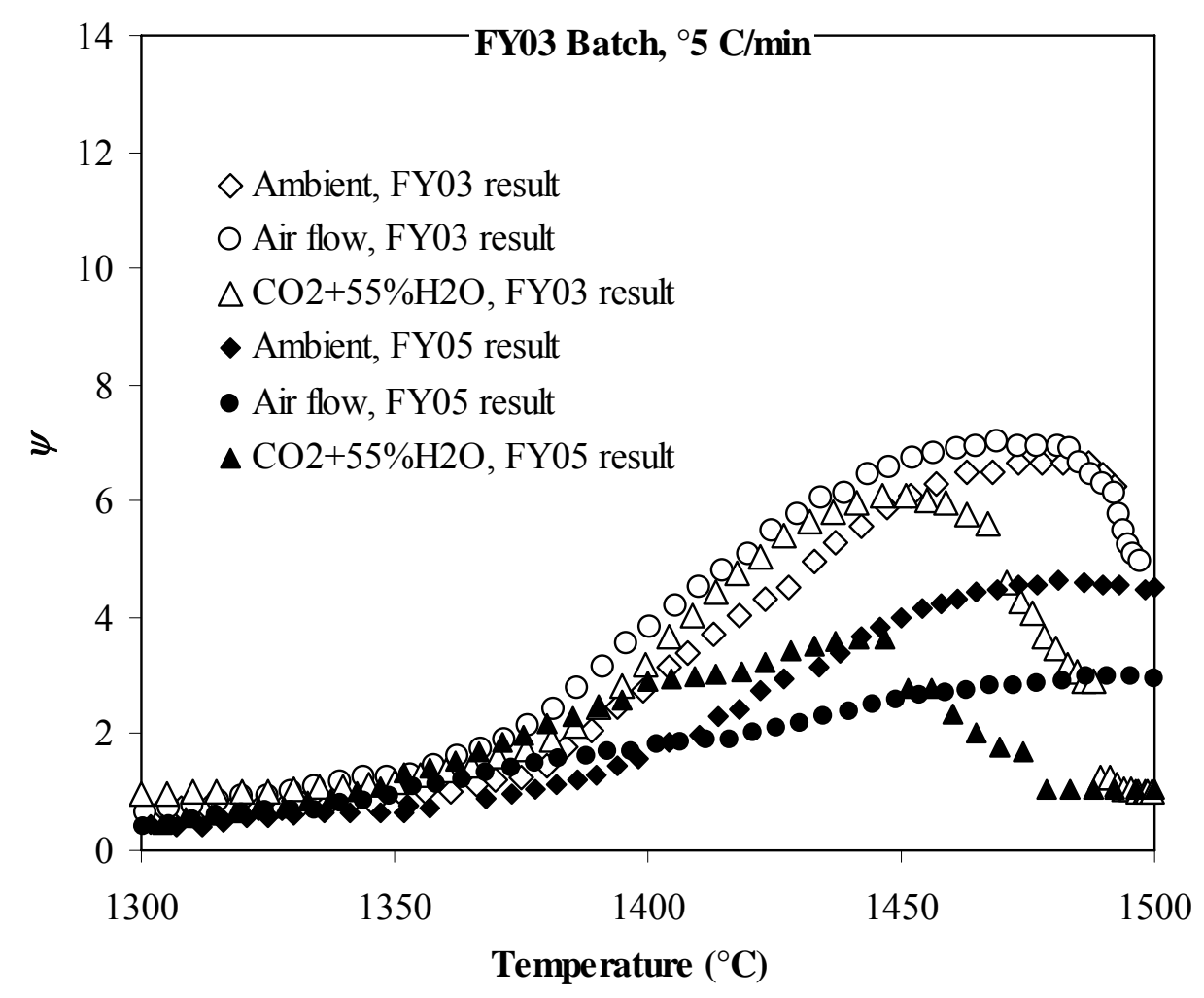

Figure 3.7. $\psi$ Versus Temperature Showing the Effect of Atmosphere on Foaming

\subsection{Sulfur Analyses on FY03 Test Glasses}

The results of sulfate analyses are summarized in Table 3.1. Figure 3.8 shows a plot of $w t \% \mathrm{SO}_{3}$ versus temperature for three sets of atmospheric conditions. Error bars represent an estimated analytical uncertainty of $\pm 15 \%$. During heating from $300^{\circ} \mathrm{C}$ to $1250^{\circ} \mathrm{C}$, the batch heated under $45 \% \mathrm{CO}_{2}+55 \%$ $\mathrm{H}_{2} \mathrm{O}$ atmosphere lost $\sim 80 \%$ of the sulfate whereas the batch heated under ambient atmosphere had no measurable sulfate loss within analytical uncertainty. This result confirms our reasoning that the lack of foaming in Test 13 (the test under $\mathrm{CO}_{2}+55 \% \mathrm{H}_{2} \mathrm{O}$ atmosphere with the gas introduced at $300^{\circ} \mathrm{C}$, see Figure 3.1e) is caused by a loss of sulfate at $T<1250^{\circ} \mathrm{C}$ because of higher water content at the early stages of melting (Kim et al. 2004). During heating from 1250 to $1500^{\circ} \mathrm{C}$, the batch heated under $45 \% \mathrm{CO}_{2}+$ $55 \% \mathrm{H}_{2} \mathrm{O}$ atmosphere had a somewhat larger sulfate loss than the batch heated under air flow. This suggests that introducing the humid gas flow when the temperature reached $1250^{\circ} \mathrm{C}$ also produced the dilution effect to some extent. However, reduced foaming under humid atmospheres observed in the present study under crucible melting conditions suggests that the effect of reduced surface viscosity caused by dissolved water which decreases foaming outweighed the dilution effect which increases foaming (Kim et al. 2004). 
Table 3.1. $\mathrm{SO}_{3} \mathrm{wt} \%$ Measured in Glasses after Heating to 1250 or $1500^{\circ} \mathrm{C}$ under Various Atmospheres

\begin{tabular}{|c|c|c|c|}
\hline $\begin{array}{l}\text { FY03 Test } \\
\text { Number }\end{array}$ & $300-1250{ }^{\circ} \mathrm{C}$ & $1250-1500{ }^{\circ} \mathrm{C}$ & $\mathrm{SO}_{3} \mathrm{wt} \%$ \\
\hline 1 & Ambient & Air flow & 0.083 \\
\hline 8 & Ambient & $\mathrm{CO}_{2}+55 \% \mathrm{H}_{2} \mathrm{O}$ & 0.050 \\
\hline 13 & $\mathrm{CO}_{2}+55 \% \mathrm{H}_{2} \mathrm{O}$ & $\mathrm{CO}_{2}+55 \% \mathrm{H}_{2} \mathrm{O}$ & 0.032 \\
\hline 1 (or 8) modified & Ambient & $\mathrm{N} / \mathrm{A}$ & 0.187 \\
\hline 13 modified & $\mathrm{CO}_{2}+55 \% \mathrm{H}_{2} \mathrm{O}$ & $\mathrm{N} / \mathrm{A}$ & 0.035 \\
\hline \multicolumn{4}{|c|}{$\begin{array}{l}\text { Test \# refers to the FY03 test matrix in Kim et al. } 2004 \text {. } \\
\text { N/A: not applicable; heating was stopped at } 1250^{\circ} \mathrm{C} \text {. }\end{array}$} \\
\hline
\end{tabular}

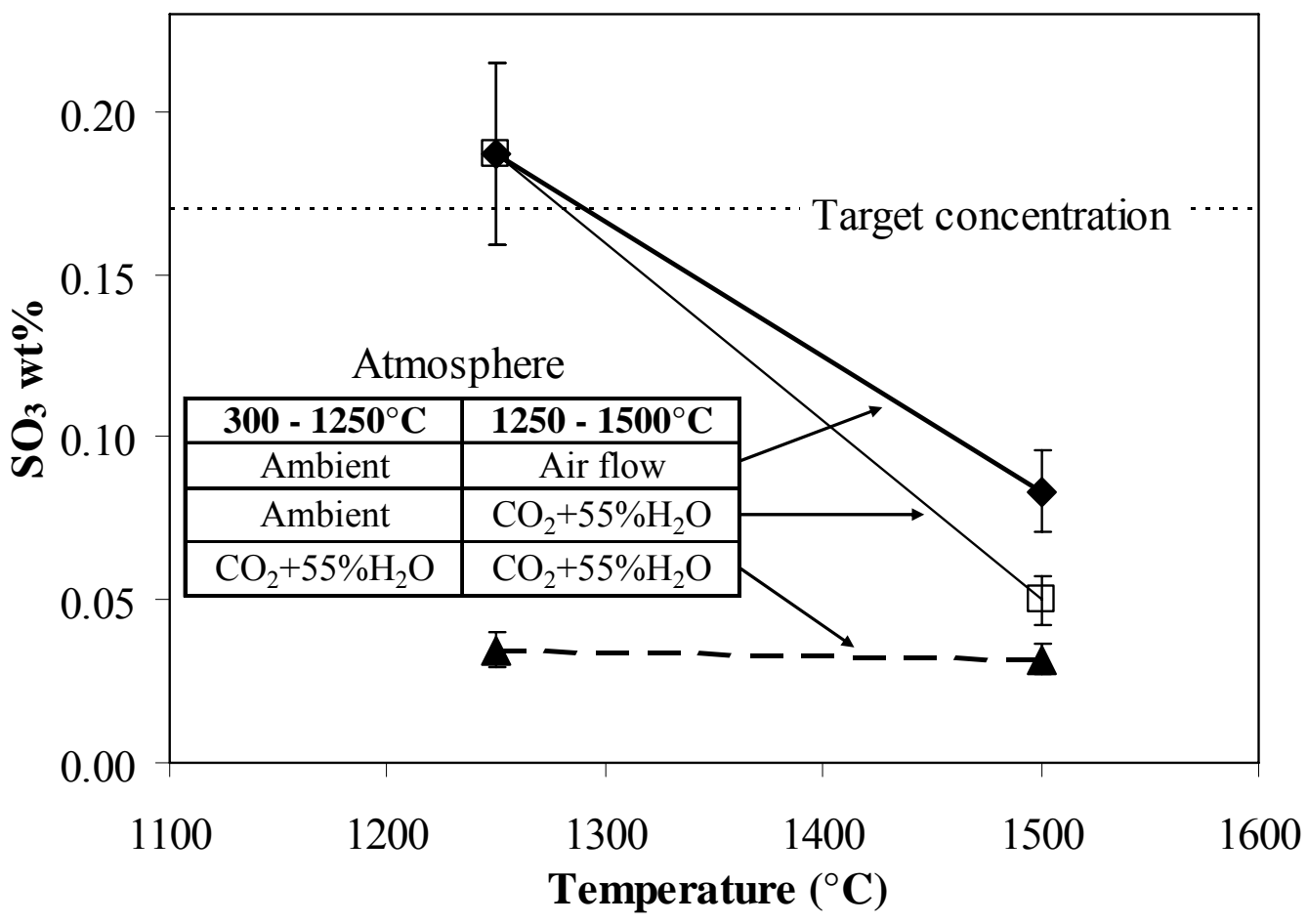

Figure 3.8. $\mathrm{SO}_{3} \mathrm{wt} \%$ in Final Glass Versus Temperature (The trend lines are for visual guidance only)

\subsection{Tests with FY05 Batches}

Table 3.2 shows the test matrix for the foaming tests with FY05 batches. Tests number 13, 15, and 17 to be conducted at a heating rate of $5{ }^{\circ} \mathrm{C} / \mathrm{min}$ in ambient or controlled atmosphere with GPlus $05 \mathrm{E}$ and GPlus $05 \mathrm{~F}$ batches were not performed because the corresponding tests at $10{ }^{\circ} \mathrm{C} / \mathrm{min}$ did not produce foam (in general foam increases as heating rate increases). These are not included in Table 3.2. 
Table 3.2. Test Matrix for FY05 Foaming Tests

\begin{tabular}{|c|c|c|c|c|}
\hline Test \# & Batch ID & $\begin{array}{l}\text { Mass of } \\
\text { batch } \\
\text { (g) }\end{array}$ & Atmosphere & $\begin{array}{c}\text { Heating } \\
\text { rate } \\
\left({ }^{\circ} \mathrm{C} / \mathrm{min}\right)\end{array}$ \\
\hline FY05-1a & Gplus05A & 4.000 & Ambient & 5 \\
\hline FY05-2a & Gplus05A & 4.000 & Ambient & 10 \\
\hline FY05-3a & Gplus05A & 4.000 & Air flow introduced at $1250^{\circ} \mathrm{C}$ & 5 \\
\hline FY05-1 & Gplus05A & 3.500 & Ambient & 5 \\
\hline FY05-2 & Gplus05A & 3.500 & Ambient & 10 \\
\hline FY05-3 & Gplus05A & 3.500 & Air flow introduced at $1250^{\circ} \mathrm{C}$ & 5 \\
\hline FY05-4 & Gplus05A & 3.500 & $\mathrm{CO}_{2}+55 \% \mathrm{H}_{2} \mathrm{O}$ introduced at $1250^{\circ} \mathrm{C}$ & 5 \\
\hline FY05-5 & Gplus05B & 3.706 & Ambient & 5 \\
\hline FY05-6 & Gplus05B & 3.500 & Ambient & 10 \\
\hline FY05-7 & Gplus05C & 3.994 & Ambient & 5 \\
\hline FY05-8 & Gplus05C & 3.500 & Ambient & 10 \\
\hline FY05-9 & Gplus05B & 3.706 & $\mathrm{CO}_{2}+55 \% \mathrm{H}_{2} \mathrm{O}$ introduced at $1250^{\circ} \mathrm{C}$ & 5 \\
\hline FY05-10 & Gplus05D & 3.500 & Ambient & 5 \\
\hline FY05-11 & Gplus05D & 3.500 & Ambient & 10 \\
\hline FY05-12 & Gplus05D & 3.500 & $\mathrm{CO}_{2}+55 \% \mathrm{H}_{2} \mathrm{O}$ introduced at $1250^{\circ} \mathrm{C}$ & 5 \\
\hline FY05-14 & Gplus05E & 3.500 & Ambient & 10 \\
\hline FY05-16 & Gplus05F & 3.500 & Ambient & 10 \\
\hline FY05-20 & $\begin{array}{l}75 \% \text { GPlus } 05 \mathrm{~A} \text { and } \\
25 \% \text { GPlus } 05 \mathrm{D}\end{array}$ & 3.500 & Ambient & 5 \\
\hline FY05-21 & $\begin{array}{l}75 \% \text { GPlus } 05 \mathrm{~A} \text { and } \\
25 \% \text { GPlus } 05 \mathrm{D}\end{array}$ & 3.500 & Ambient & 10 \\
\hline FY05-22 & $\begin{array}{l}50 \% \text { GPlus } 05 \mathrm{~A} \text { and } \\
50 \% \text { GPlus } 05 \mathrm{D}\end{array}$ & 3.500 & Ambient & 5 \\
\hline FY05-23 & $\begin{array}{l}50 \% \text { GPlus05A and } \\
50 \% \text { GPlus05D }\end{array}$ & 3.500 & Ambient & 10 \\
\hline FY05-24 & $\begin{array}{l}25 \% \text { GPlus } 05 \mathrm{~A} \text { and } \\
75 \% \text { GPlus05D }\end{array}$ & 3.500 & Ambient & 5 \\
\hline FY05-25 & $\begin{array}{l}25 \% \text { GPlus05A and } \\
75 \% \text { GPlus05D }\end{array}$ & 3.500 & Ambient & 10 \\
\hline
\end{tabular}

Test IDs \#18 and 19 were omitted accidentally.

\subsubsection{Foaming of Baseline Batch}

Figure 3.9 shows $\psi$ as a function of temperature for tests conducted with the FY05 baseline batch (GPlus05A) and Figure 3.10 shows the $\psi$ as a function of temperature for tests conducted in this study with FY03 batch. Separate plots were used to evaluate the effect of different batches (FY03 or FY05 batch), batch size, heating rate, and atmosphere on foaming. Figure 3.11 shows that the FY05 batch containing more sulfate produces a substantially higher foam than the FY03 batch. Plots in Figure 3.11, (a) to (c), show that batch size had no noticeable effect on foaming within estimated experimental 
uncertainty. Therefore, further FY05 tests were conducted with the $3.5 \mathrm{~g}$ batch to keep the maximum foam height within the observable range. Figure 3.12 shows that the increase of heating rate from 5 to $10{ }^{\circ} \mathrm{C} / \mathrm{min}$ did not produce a difference in foaming of FY05 bathes up to $1450^{\circ} \mathrm{C}$ with only a small increase within the temperature range from $1450^{\circ} \mathrm{C}$ up to $1500^{\circ} \mathrm{C}$. It is likely that the difference in foaming between 5 and $10^{\circ} \mathrm{C} / \mathrm{min}$ will continue to increase further if the batches are heated beyond $1500^{\circ} \mathrm{C}$. Unlike $\mathrm{FY} 05$ batch, the increase of heating rate from 5 to $10{ }^{\circ} \mathrm{C} / \mathrm{min}$ increased foaming of FY03 batch nearly twice within the temperature range tested up to $1500^{\circ} \mathrm{C}$. Figure 3.13 confirms the previous observation (Kim et al. 2004) that there is no noticeable difference in foaming between air flow and $\mathrm{CO}_{2}$ $+55 \% \mathrm{H}_{2} \mathrm{O}$ atmosphere, considering the test reproducibility to be within $13 \%$ as roughly estimated by $\mathrm{Kim}$ et al. (2004). Interestingly, when the FY03 batches were tested in FY05 under the $\mathrm{CO}_{2}+55 \% \mathrm{H}_{2} \mathrm{O}$ atmosphere, foam collapsed much earlier than under air flow. The same effect was observed previously in Kim et al. (2004) for the same batch. This early foam collapse under the $\mathrm{CO}_{2}+55 \% \mathrm{H}_{2} \mathrm{O}$ atmosphere was not observed in the FY05 batches.

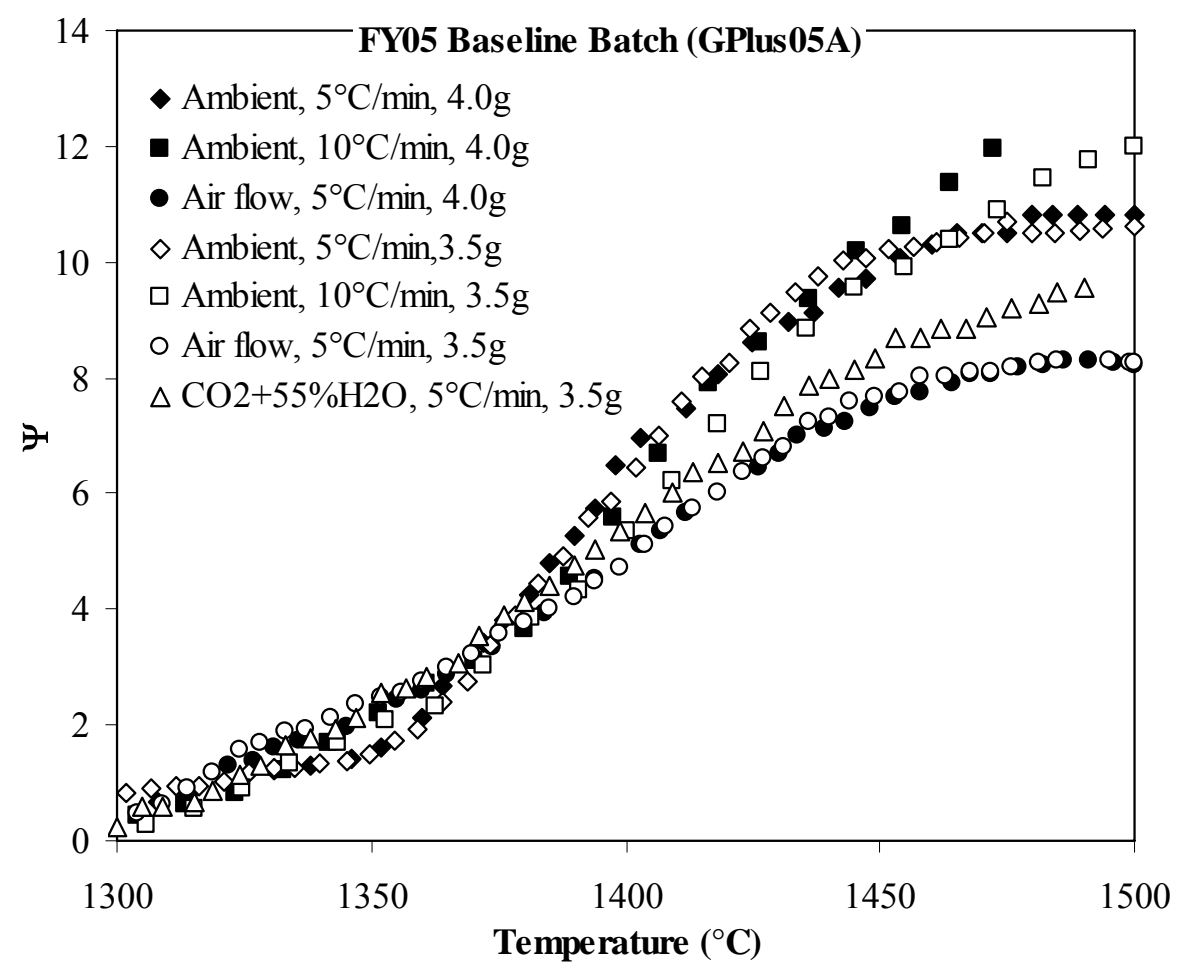

Figure 3.9. $\psi$ Versus Temperature for Tests with Baseline FY05 Batch (GPlus05AS) 


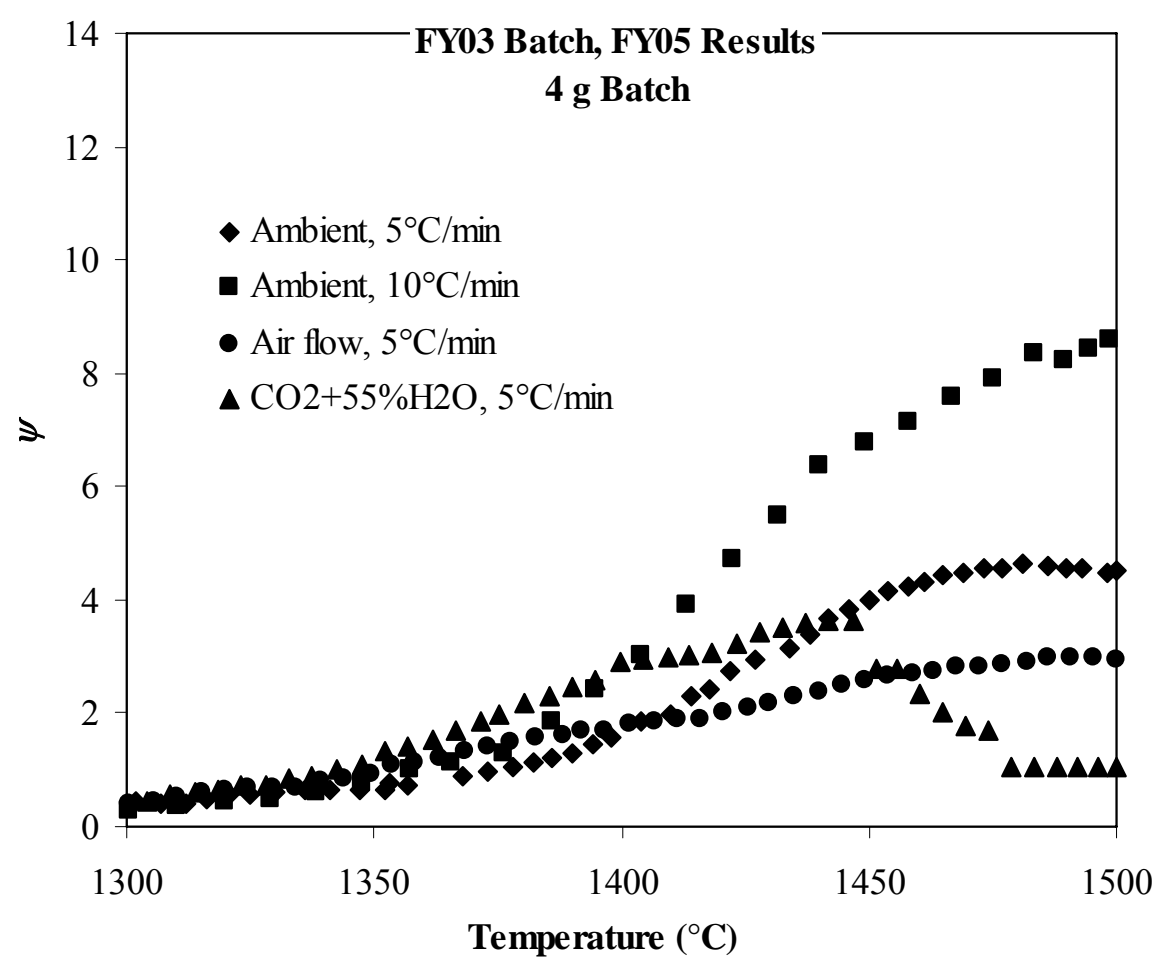

Figure 3.10. $\psi$ Versus Temperature for Tests with the FY03 Batch (Performed in FY05)
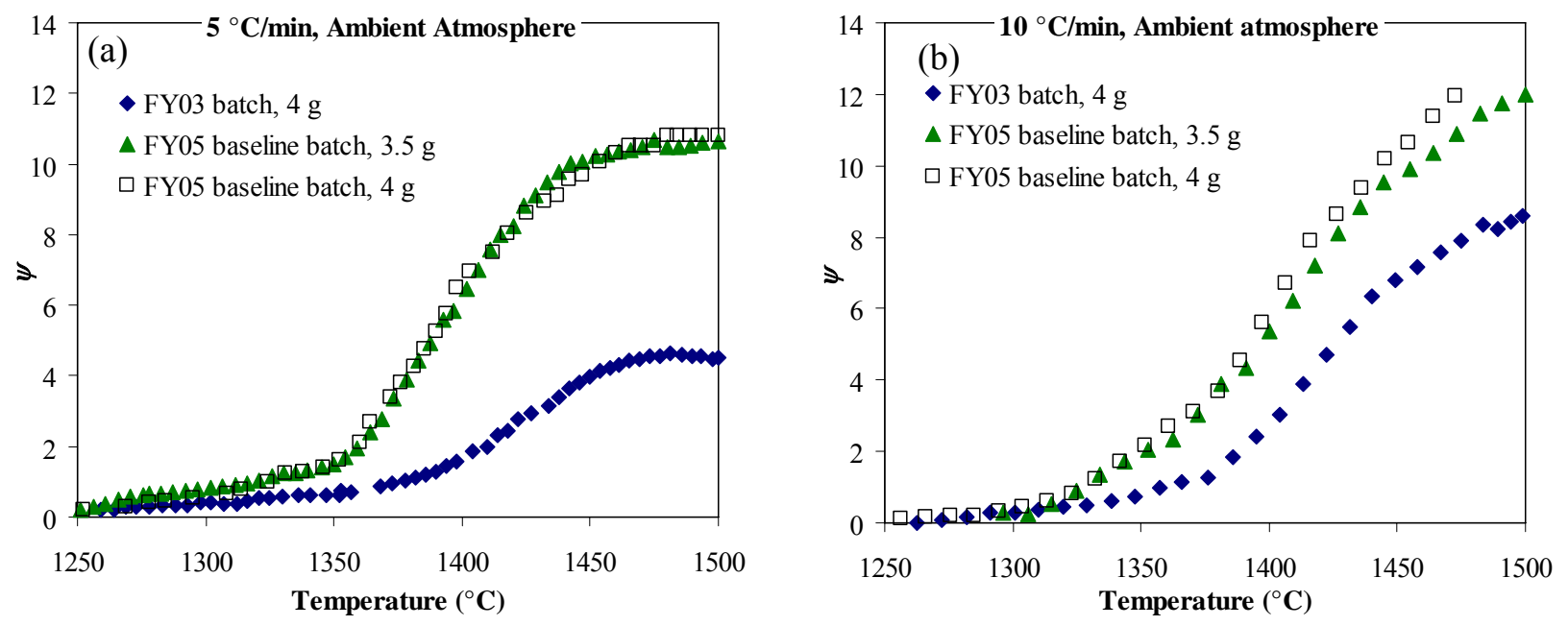

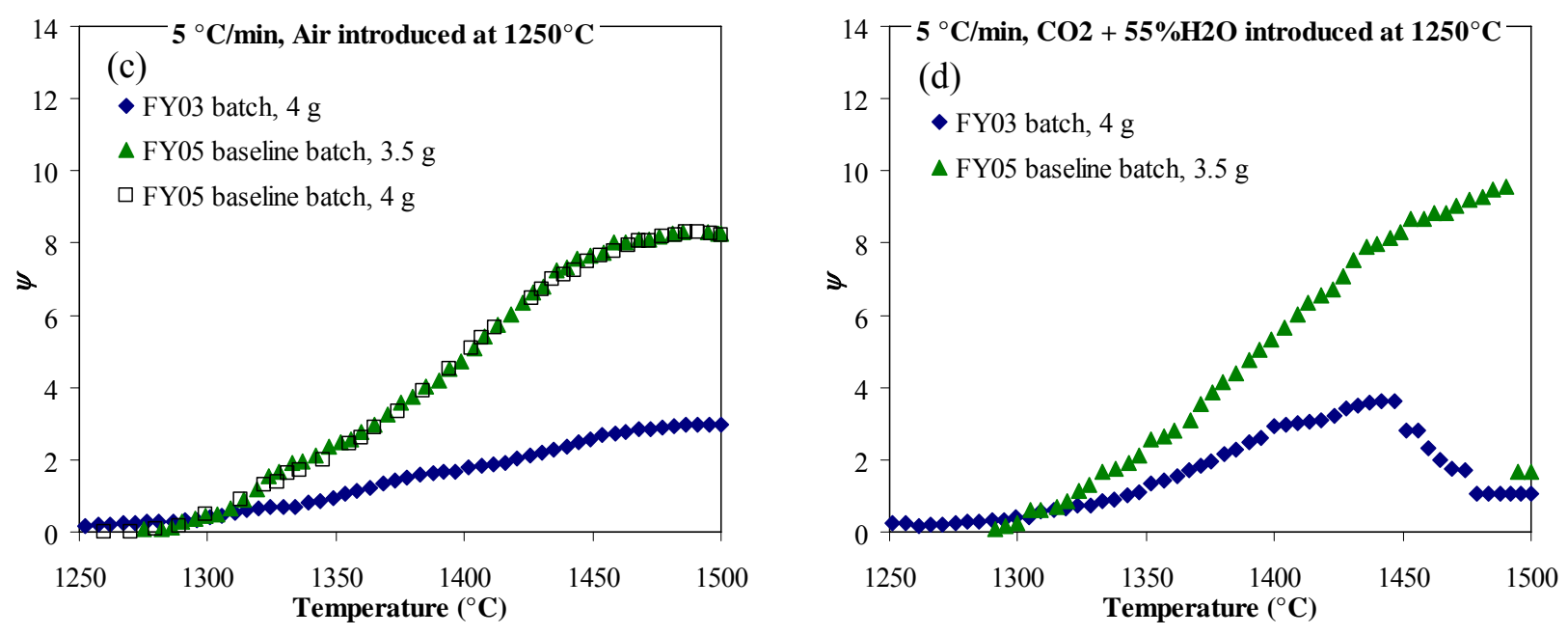

Figure 3.11. Foaming Plots to Compare Foaming in FY03 and FY05 Batches under Various Conditions. (a) Ambient, $5{ }^{\circ} \mathrm{C} / \mathrm{min}$; (b) Ambient, $10{ }^{\circ} \mathrm{C} / \mathrm{min}$; (c) Air flow introduced at $1250^{\circ} \mathrm{C}, 5^{\circ} \mathrm{C} / \mathrm{min}$; and (d) $\mathrm{CO}_{2}+55 \% \mathrm{H}_{2} \mathrm{O}$ introduced at $1250^{\circ} \mathrm{C}, 5^{\circ} \mathrm{C} / \mathrm{min}$

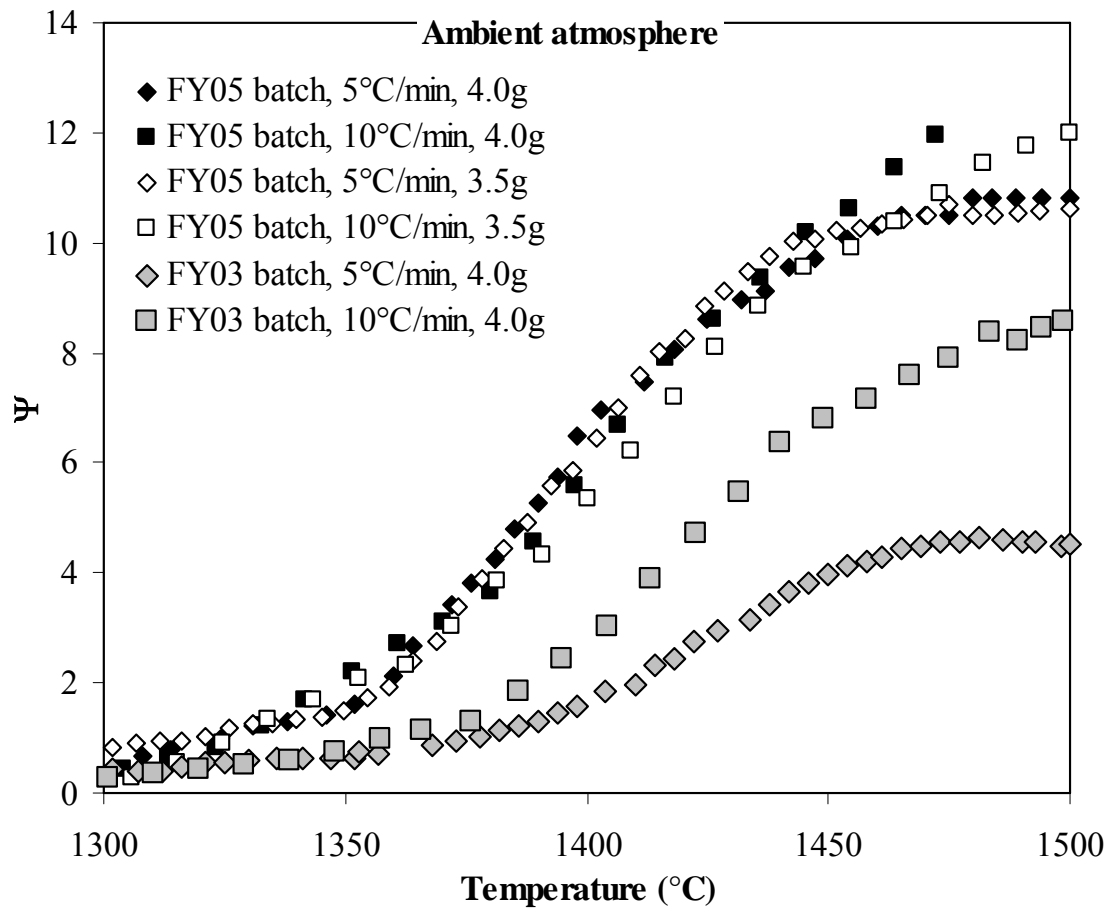

Figure 3.12. $\psi$ Versus Temperature for Tests under Ambient Atmosphere Showing the Different Effect of Heating Rate in FY03 and FY05 Batches 


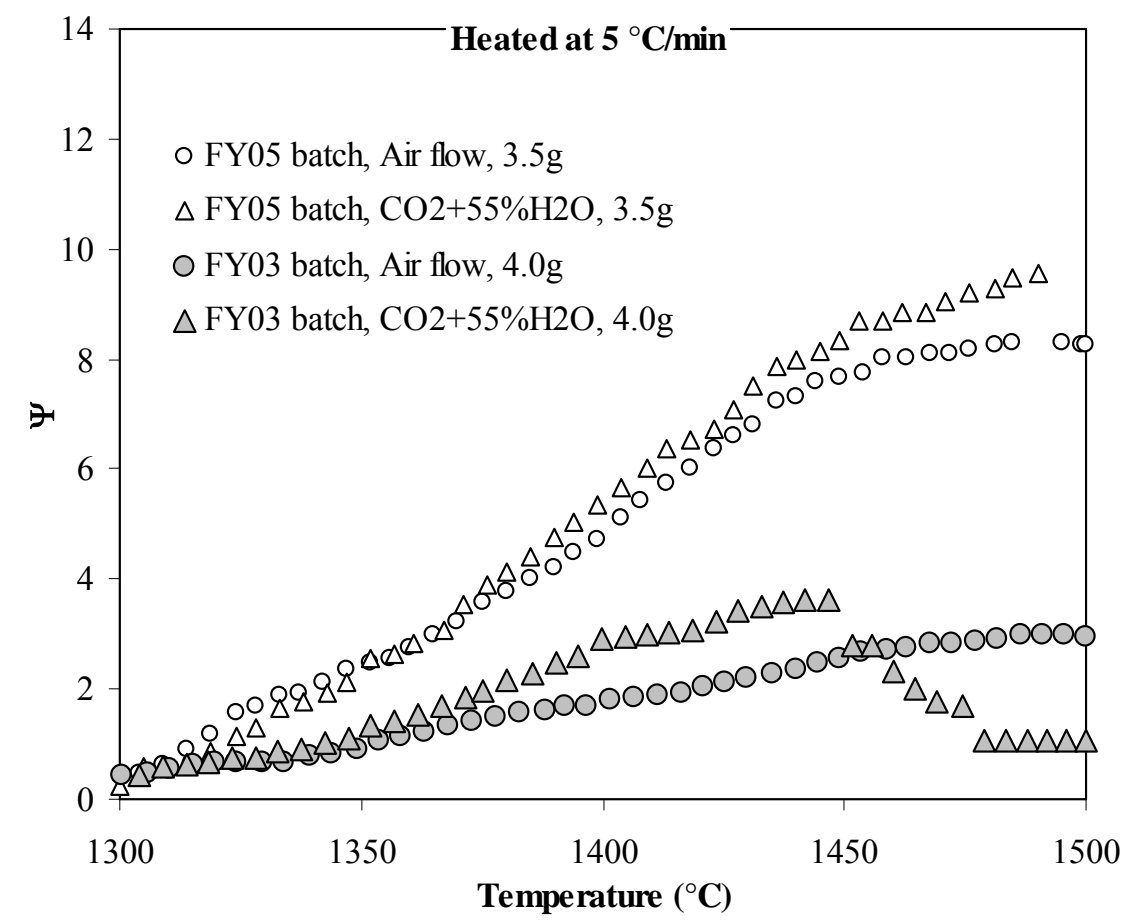

Figure 3.13. $\psi$ Versus Temperature for Tests at $5{ }^{\circ} \mathrm{C} / \mathrm{min}$ Showing the Effect of Atmosphere in FY03 and FY05 Batches

\subsubsection{Replacing Quicklime with Limestone}

Figure 3.14 and Figure 3.15 show the effect of replacing quicklime with limestone in the baseline batch. Replacing 50\% quicklime with limestone did not have any effect on foaming at both 5 and $10{ }^{\circ} \mathrm{C} / \mathrm{min}$ heating rates. Replacing $100 \%$ quicklime with limestone decreased foaming only at $5{ }^{\circ} \mathrm{C} / \mathrm{min}$ heating rate, and had no effect at $10^{\circ} \mathrm{C} / \mathrm{min}$ heating rate until $1500^{\circ} \mathrm{C}$, when the test was terminated. Replacing quicklime with limestone shows a tendency to decrease foaming and this effect would probably be manifest even at the $10{ }^{\circ} \mathrm{C} / \mathrm{min}$ heating rate if the test continued beyond $1500^{\circ} \mathrm{C}$. However, more tests would be needed to confirm the effect of replacing quicklime with limestone.

We can reason that the effect of replacing the quicklime with limestone on batch melting reaction will in turn affect the sulfate decomposition. One possible explanation would be that the generation of $\mathrm{CO}_{2}$ from limestone may increase sulfate loss during early stages of melting. Figure 3.16 compares the baseline batch with and without $50 \%$ quicklime replaced with limestone under ambient condition and under $\mathrm{CO}_{2}+$ $55 \% \mathrm{H}_{2} \mathrm{O}$ atmosphere. The observed decrease in foaming under $\mathrm{CO}_{2}+55 \% \mathrm{H}_{2} \mathrm{O}$ atmosphere compared to under ambient condition, both in the baseline and the batch with $50 \%$ quicklime replaced with limestone, is as expected from the previous study on the effect of humidity on foaming. 


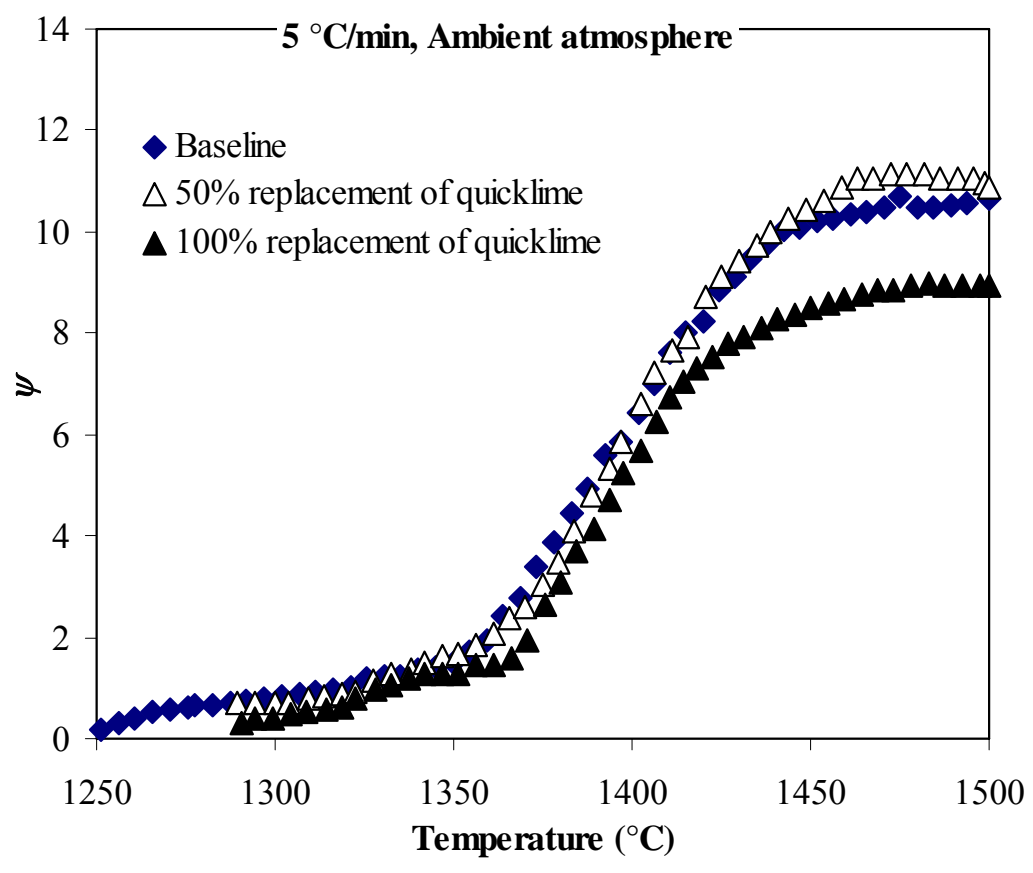

Figure 3.14. $\psi$ Versus Temperature for Tests at $5{ }^{\circ} \mathrm{C} / \mathrm{min}$ under Ambient Atmosphere Showing the Effect of Replacing Quicklime with Limestone

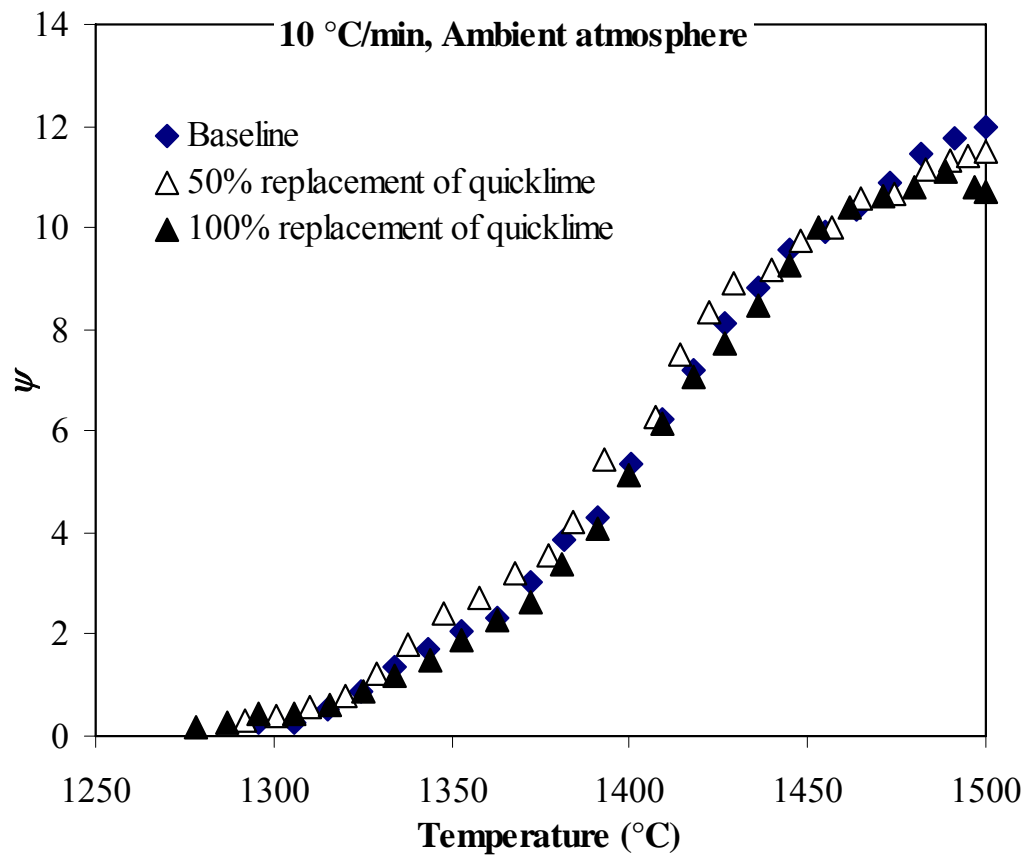

Figure 3.15. $\psi$ Versus Temperature for Tests at $10^{\circ} \mathrm{C} / \mathrm{min}$ under Ambient Atmosphere Showing the Effect of Replacing Quicklime with Limestone 


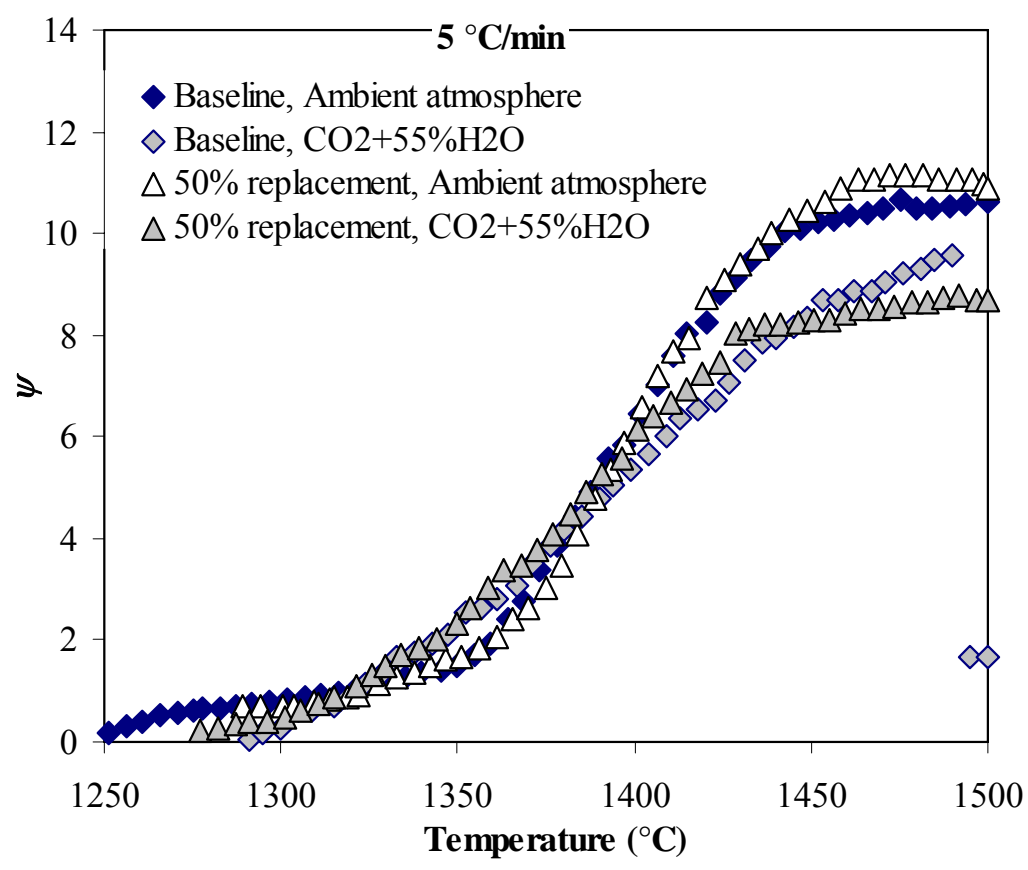

Figure 3.16. $\psi$ Versus Temperature for Baseline and $50 \%$ Limestone Batch Heated at $5{ }^{\circ} \mathrm{C} / \mathrm{min}$ under ambient and $\mathrm{CO}_{2}+55 \% \mathrm{H}_{2} \mathrm{O}$ Atmosphere

\subsubsection{0\% Replacement of $\mathrm{Na}_{2} \mathrm{SO}_{4}$ with $\mathrm{NaNO}_{3}$ and/or $\mathrm{CeO}_{2}$}

Figure 3.17 shows that the replacement of $100 \% \mathrm{Na}_{2} \mathrm{SO}_{4}$ with $\mathrm{NaNO}_{3}$ almost eliminated foaming under both ambient and $\mathrm{CO}_{2}+55 \% \mathrm{H}_{2} \mathrm{O}$ atmospheres; $\psi$ increased only very slightly at $5^{\circ} \mathrm{C} / \mathrm{min}$ up to $1500^{\circ} \mathrm{C}$, though somewhat more at $10{ }^{\circ} \mathrm{C} / \mathrm{min}$, probably due to the sulfate present as impurity in raw materials. It is likely that further increase of temperature beyond $1500^{\circ} \mathrm{C}$ may show clear increase of foaming at $10{ }^{\circ} \mathrm{C} / \mathrm{min}$. Figure 3.18 shows that only very limited foaming occurs in the batches when $\mathrm{Na}_{2} \mathrm{SO}_{4}$ is fully replaced with $\mathrm{NaNO}_{3}, \mathrm{NaNO}_{3}+\mathrm{CeO}_{2}$, and $\mathrm{CeO}_{2}$ regardless of the replacing components. 


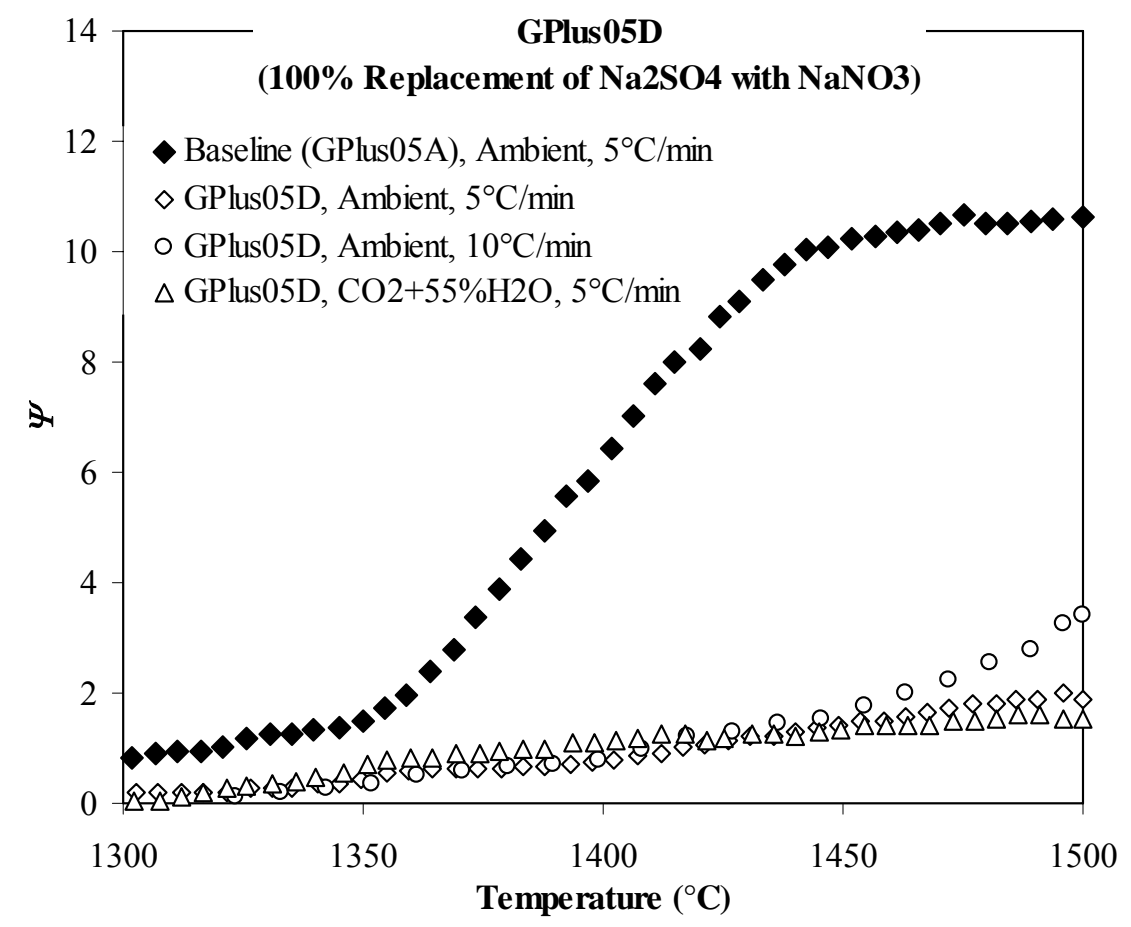

Figure 3.17. $\psi$ Versus Temperature in the Batches with $100 \% \mathrm{Na}_{2} \mathrm{SO}_{4}$ Replaced with $\mathrm{NaNO}_{3}$ Compared with the Baseline Batch

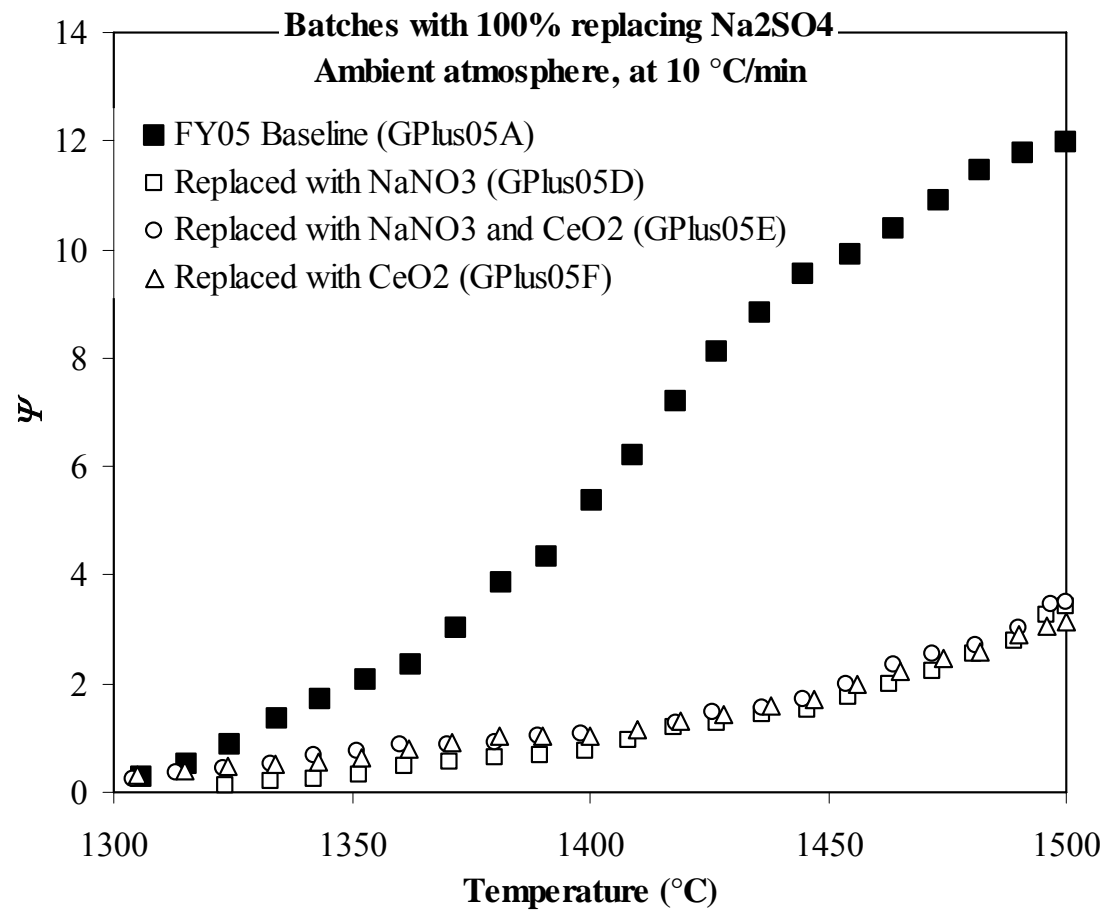

Figure 3.18. $\psi$ Versus Temperature in the Batches with $100 \% \mathrm{Na}_{2} \mathrm{SO}_{4}$ Replaced with $\mathrm{NaNO}_{3}$, $\mathrm{NaNO}_{3}$ and $\mathrm{CeO}_{2}$, and $\mathrm{CeO}_{2} \mathrm{Compared}$ with the Baseline Batch 


\subsubsection{Gradual Replacement of $\mathrm{Na}_{2} \mathrm{SO}_{4}$ with $\mathrm{NaNO}_{3}$}

To investigate the effect of gradually replacing $\mathrm{Na}_{2} \mathrm{SO}_{4}$ with $\mathrm{NaNO}_{3}$, new batches were made up using GPlus05A and GPlus05D batches: 25\% replacement (75\% GPlus05A and 25\% GPlus05D), 50\% replacement (50\% GPlus05A and 50\% GPlus05D), and 75\% replacement (25\% GPlus05A and 75\% GPlus05D). Each of these variations was made in 16-g batches by mixing in an agate mill for 4 minutes. These batches were tested under ambient atmosphere at 5 and $10^{\circ} \mathrm{C} / \mathrm{min}$.

Figure 3.19 and Figure 3.20 show the decreasing trend of foaming with progressing replacement of $\mathrm{Na}_{2} \mathrm{SO}_{4}$ by $\mathrm{NaNO}_{3}$ over the temperature range explored. Figure 3.21 shows five sets of plots showing the effect of the heating rate in each batch with varied fractions of $\mathrm{Na}_{2} \mathrm{NO}_{3}$ replacement. Interestingly, the difference in maximum $\psi$ between 5 and $10{ }^{\circ} \mathrm{C} / \mathrm{min}$ heating rate increases from the baseline to $50 \%$ replacement and then decreases as the replacement reaches $100 \%$.

Figure 3.22 summarizes the effect of percent replacement of $\mathrm{Na}_{2} \mathrm{SO}_{4}$ with $\mathrm{NaNO}_{3}$ on the maximum $\psi$ that is used as key measure of foaming extent. The maximum $\psi$ decreased as the replacement of $\mathrm{Na}_{2} \mathrm{SO}_{4}$ with $\mathrm{NaNO}_{3}$ increased. The two horizontal lines included in Figure 3.22 represent the maximum $\psi$ for the FY03 batches tested in the present study. Another measure of foaming extent is the melt expansion rate, $\mathrm{d} \psi / \mathrm{d} T$. Figure 3.23 shows the data points on the linear portion of the foaming curve used to obtain the slope $\mathrm{d} \psi / \mathrm{d} T$ and Figure 3.24 summarizes the effect of percent replacement of $\mathrm{Na}_{2} \mathrm{SO}_{4}$ with $\mathrm{NaNO}_{3}$ on $\mathrm{d} \psi / \mathrm{d} T$. The two horizontal lines also represent the maximum $\mathrm{d} \psi / \mathrm{d} T$ for the FY03 batches tested in the present study. The $\mathrm{d} \psi / \mathrm{d} T$ for the tests at $5{ }^{\circ} \mathrm{C} / \mathrm{min}$ decreased almost linearly with the percent replacement of $\mathrm{Na}_{2} \mathrm{SO}_{4}$, similar to maximum $\psi$, whereas the slope $\mathrm{d} \psi / \mathrm{d} T$ for the tests at $10{ }^{\circ} \mathrm{C} / \mathrm{min}$ did not change up to $50 \%$ replacement and then decreased.

For the tests at $10{ }^{\circ} \mathrm{C} / \mathrm{min}$, the change of $\mathrm{d} \psi / \mathrm{d} T$ with percent replacement of $\mathrm{Na}_{2} \mathrm{SO}_{4}$ clearly shows that there is a slope transition at a 50\% replacement (Figure 3.24) although it is not so obvious for the change of maximum $\psi$ (Figure 3.22). It is also acceptable for the maximum $\psi$ versus percent replacement of $\mathrm{Na}_{2} \mathrm{SO}_{4}$ to just draw a straight line with larger scatter. More tests would be needed to confirm the actual trend. It was assumed in Figure 3.22 that there was a slope transition at a 50\% replacement similar to the $\mathrm{d} \psi / \mathrm{d} T$ data. The results in Figure 3.24 suggest that there is a foam destabilizing effect in a batch with high sulfate content. The similar effect of high sulfate content on the maximum foam height (equivalent to $\psi$ of this study) was observed in previous foam studies with a soda-lime glass (Kim and Hrma 1992; Kokubu et al. 1977). When sulfate content exceeds a certain level, some sulfate may remain undissolved at a temperature of foam generation and form a separated salt phase that may suppress foam. This foam suppressing effect is likely more pronounced for the tests with higher heating rate, which provides a less time for sulfate to dissolve.

The two tests with FY03 batch resulted in the maximum $\psi$ and $\mathrm{d} \psi / \mathrm{d} T$ in the range that would result from FY05 batches with roughly $50 \%$ to $70 \%$ replacement of $\mathrm{Na}_{2} \mathrm{SO}_{4}$ with $\mathrm{NaNO}_{3}$ (see Figure 3.22 and Figure 3.24). Table 3.3 summarizes the target $\mathrm{SO}_{3}$ concentrations in the $\mathrm{FY} 03$ batch and $\mathrm{FY} 05$ batches with gradual replacement of $\mathrm{Na}_{2} \mathrm{SO}_{4}$ with $\mathrm{NaNO}_{3}$. The FY05 batches that resulted in the similar foaming extent to the $\mathrm{FY} 03$ batch had a target $\mathrm{SO}_{3}$ concentration of 0.15 to $0.10 \mathrm{wt} \%$, which is lower than that in the FY03 batch, $0.17 \mathrm{wt} \%$. However, it is noted that the $\mathrm{SO}_{3}$ from $\mathrm{Na}_{2} \mathrm{SO}_{4}$ was similar, i.e., $\mathrm{FY} 03$ batch 
had $0.085 \mathrm{wt} \% \mathrm{SO}_{3}$ from $\mathrm{Na}_{2} \mathrm{SO}_{4}$ while $\mathrm{FY} 05$ batches that resulted in the similar foaming extent to the FY03 batch had 0.12 to $0.07 \mathrm{wt} \%$. Considering that there are some differences between FY03 and FY05 batches in the glass composition and batch formula and source of $\mathrm{SO}_{3}$ (from $\mathrm{Na}_{2} \mathrm{SO}_{4}$ or impurity), the results from thy FY03 batch matches reasonably well with those from FY05 batches.

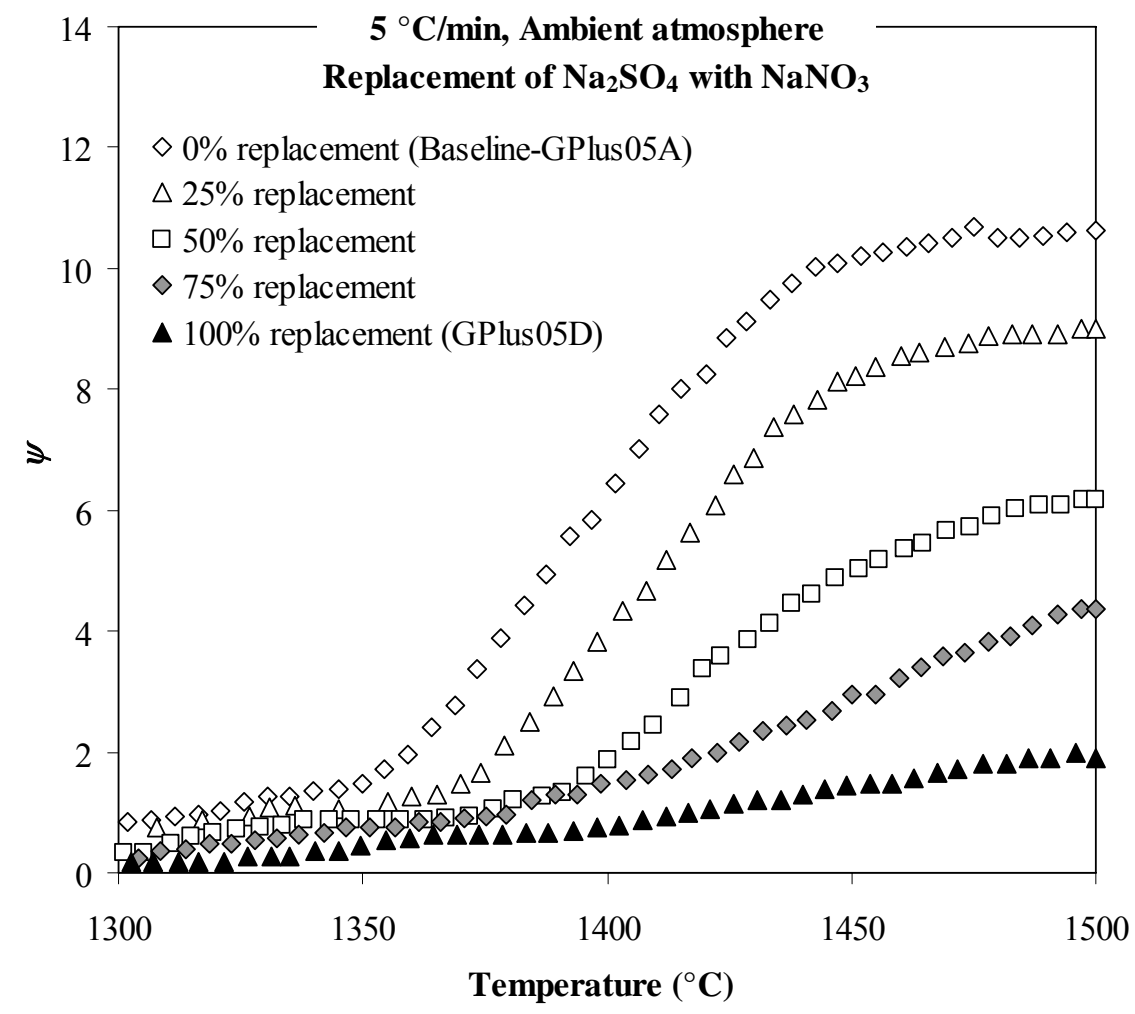

Figure 3.19. $\psi$ Versus Temperature in the Batches with 0 to $100 \% \mathrm{Na}_{2} \mathrm{SO}_{4}$ Replaced with $\mathrm{NaNO}_{3}$, Tested Under Ambient Atmosphere at $5{ }^{\circ} \mathrm{C} / \mathrm{min}$

${ }^{\text {a }}$ Not reported because it is confidential information. 


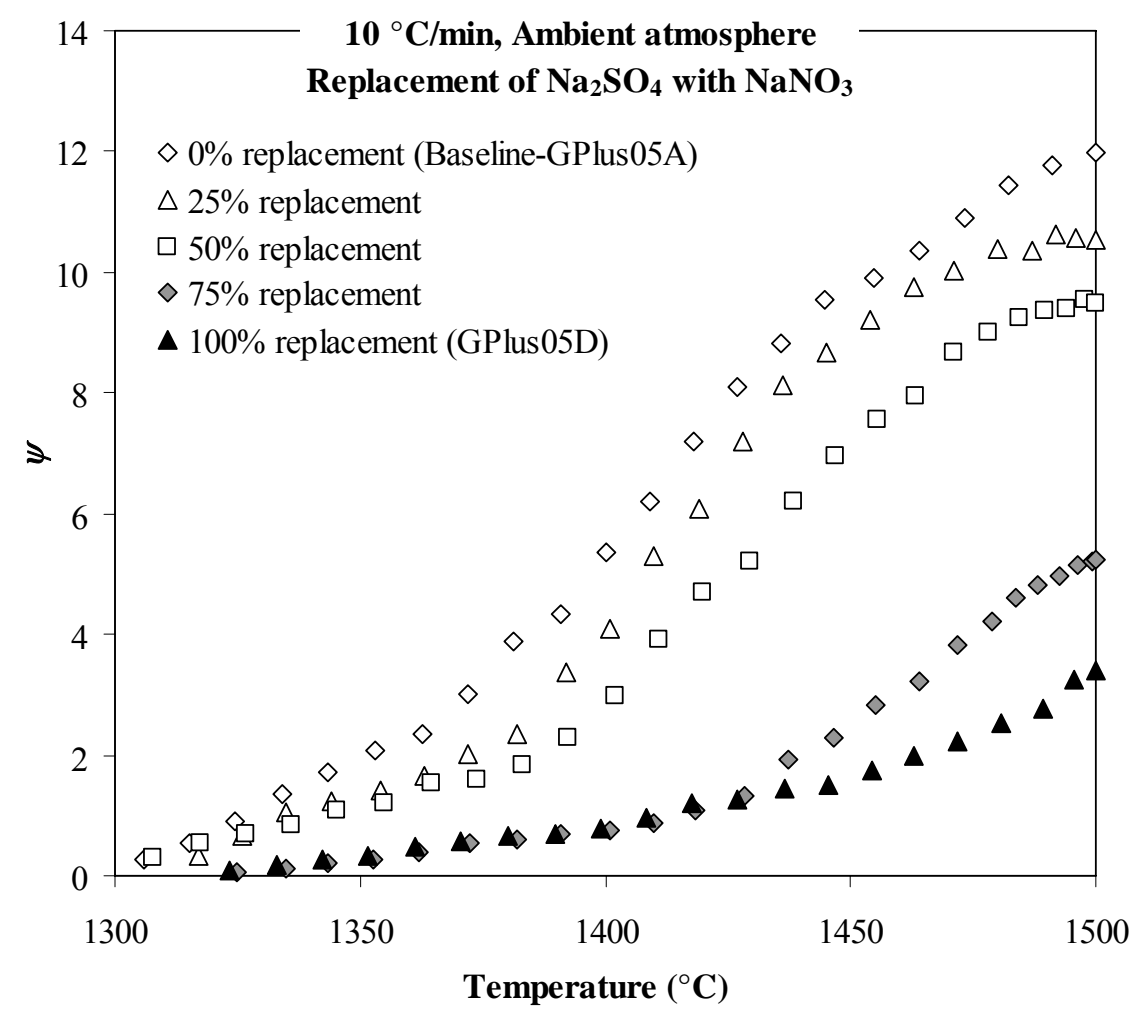

Figure 3.20. $\psi$ Versus Temperature in the Batches with 0 to $100 \% \mathrm{Na}_{2} \mathrm{SO}_{4}$ Replaced with $\mathrm{NaNO}_{3}$, Tested under Ambient Atmosphere at $10{ }^{\circ} \mathrm{C} / \mathrm{min}$
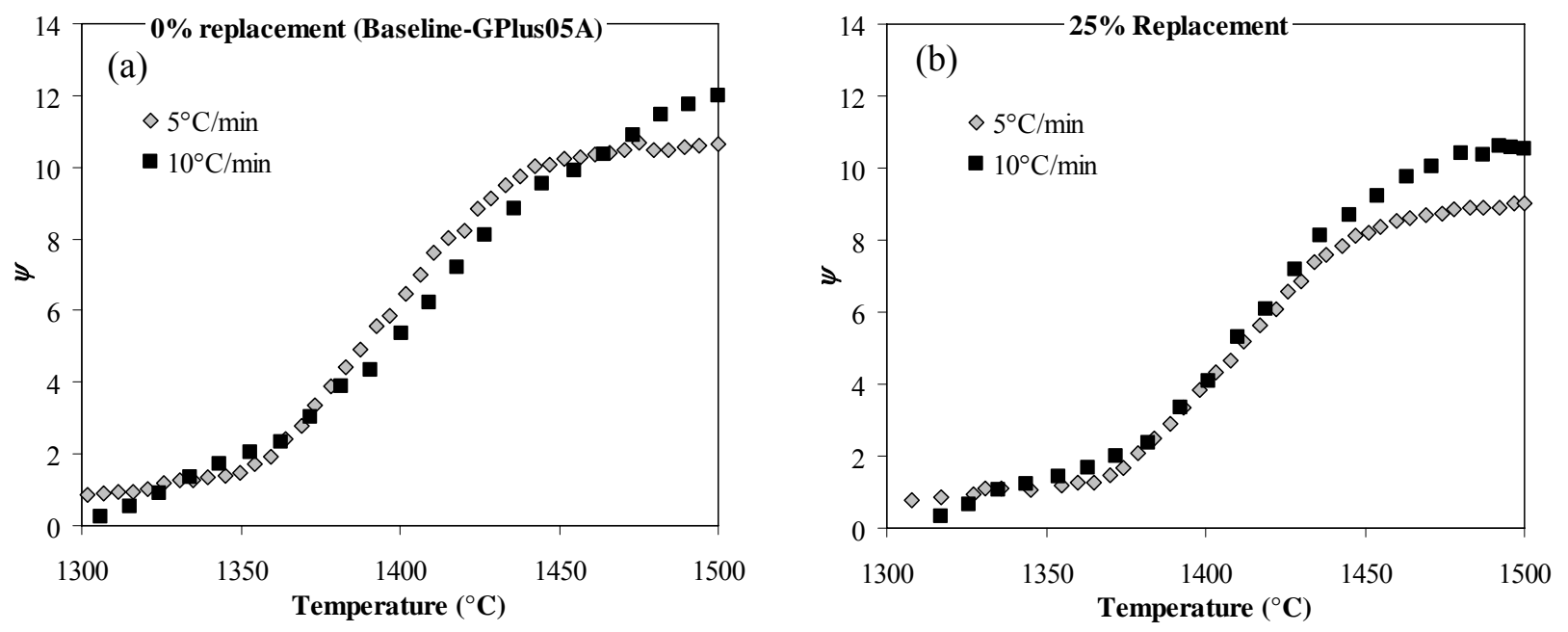

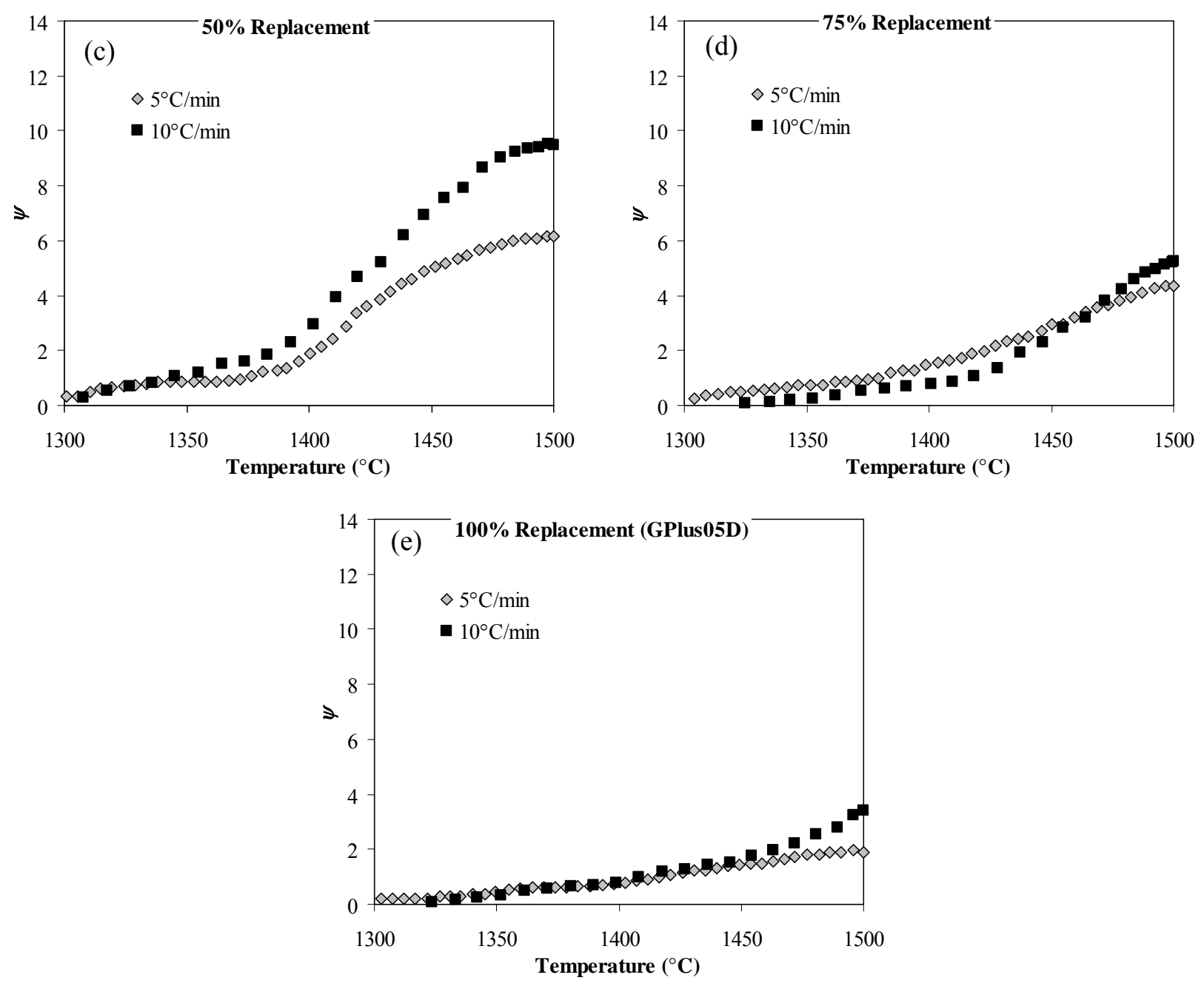

Figure 3.21. $\psi$ Versus Temperature in the Batches with 0 to $100 \% \mathrm{Na}_{2} \mathrm{SO}_{4}$ Replaced with $\mathrm{NaNO}_{3}$ Showing the Effect of Heating Rate 


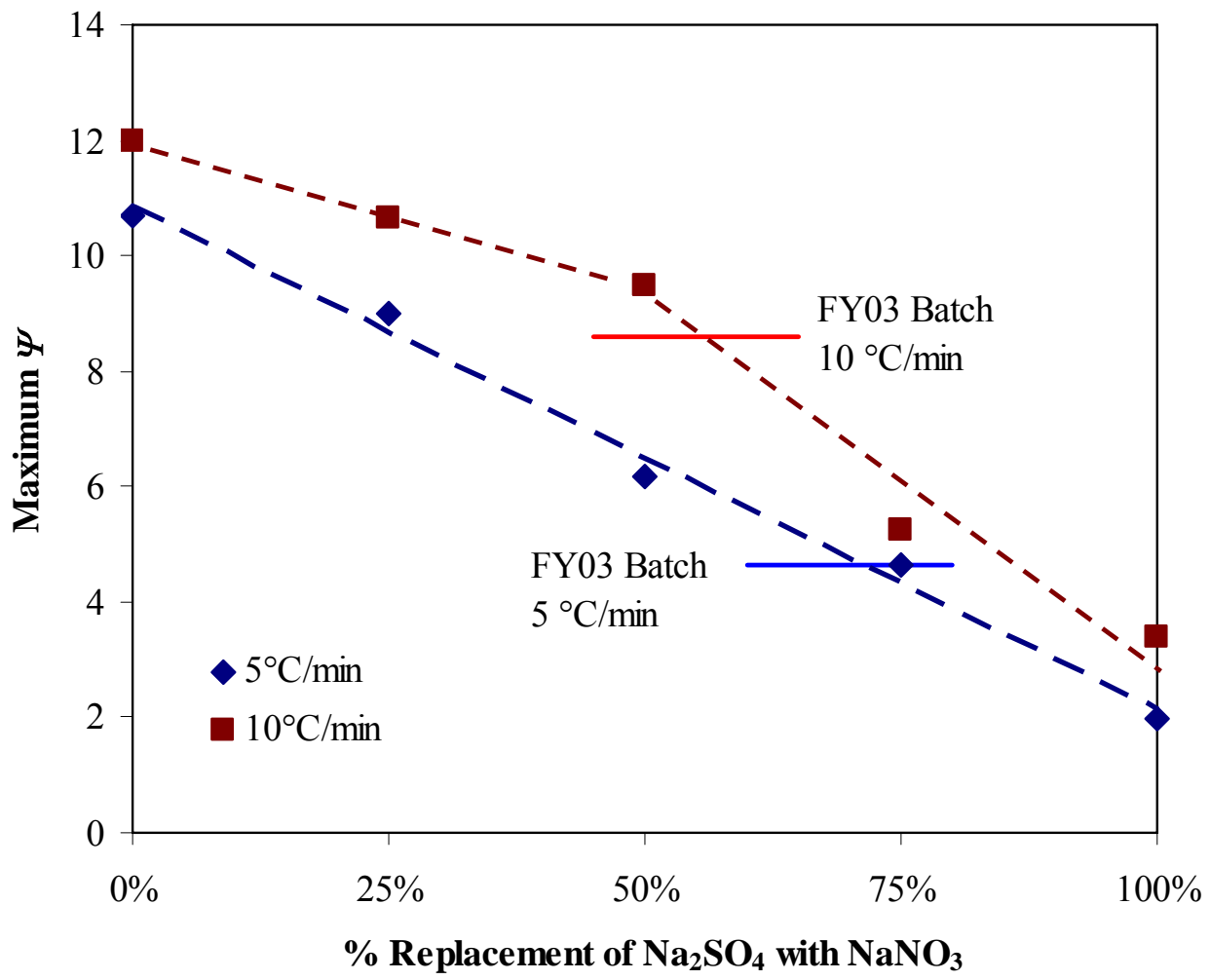

Figure 3.22. Maximum $\psi$ Versus Percent Replacement of $\mathrm{Na}_{2} \mathrm{SO}_{4}$ with $\mathrm{NaNO}_{3}$
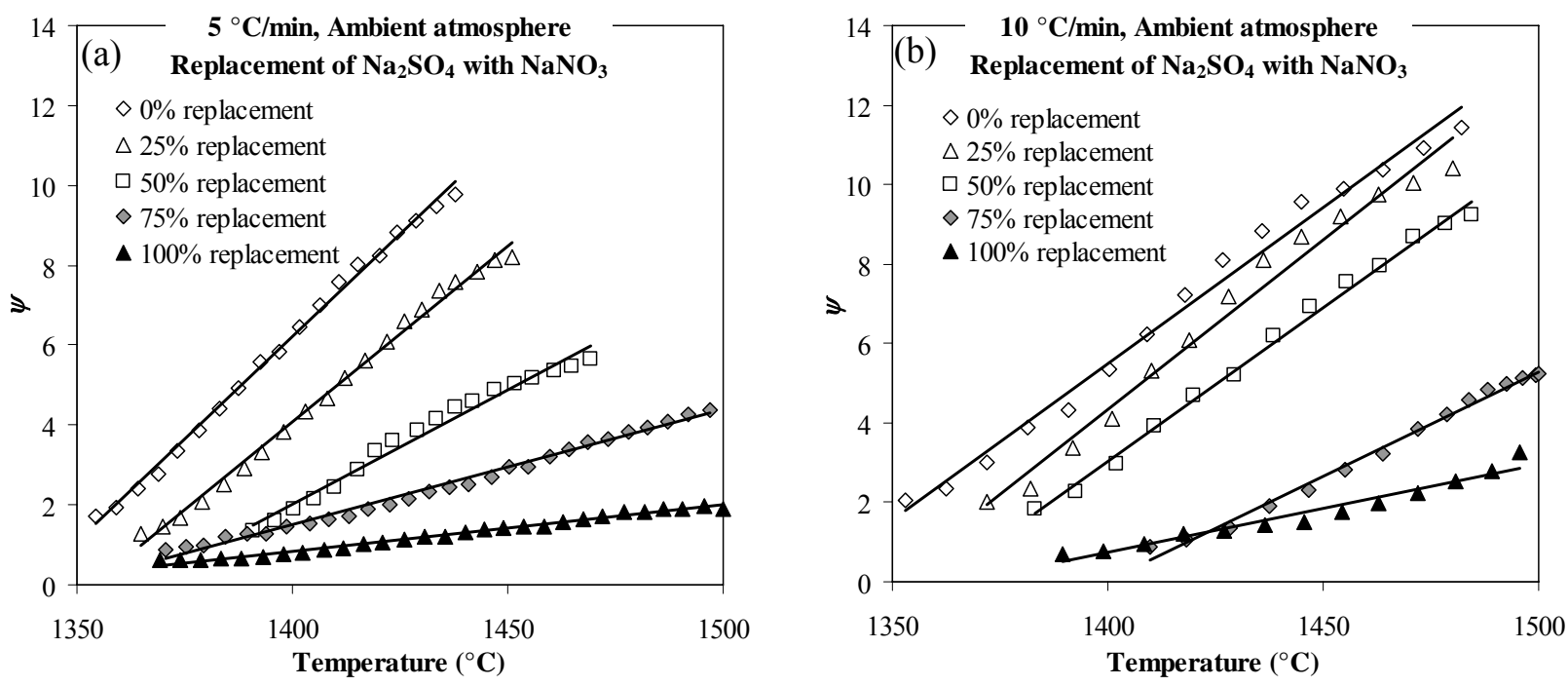

Figure 3.23. $\psi$ Versus Temperature Showing the Data Points Used to Obtain $\mathrm{d} \psi / \mathrm{dT}$ for the Tests at (a) $5^{\circ} \mathrm{C} / \mathrm{min}$ and (b) $10{ }^{\circ} \mathrm{C} / \mathrm{min}$ 


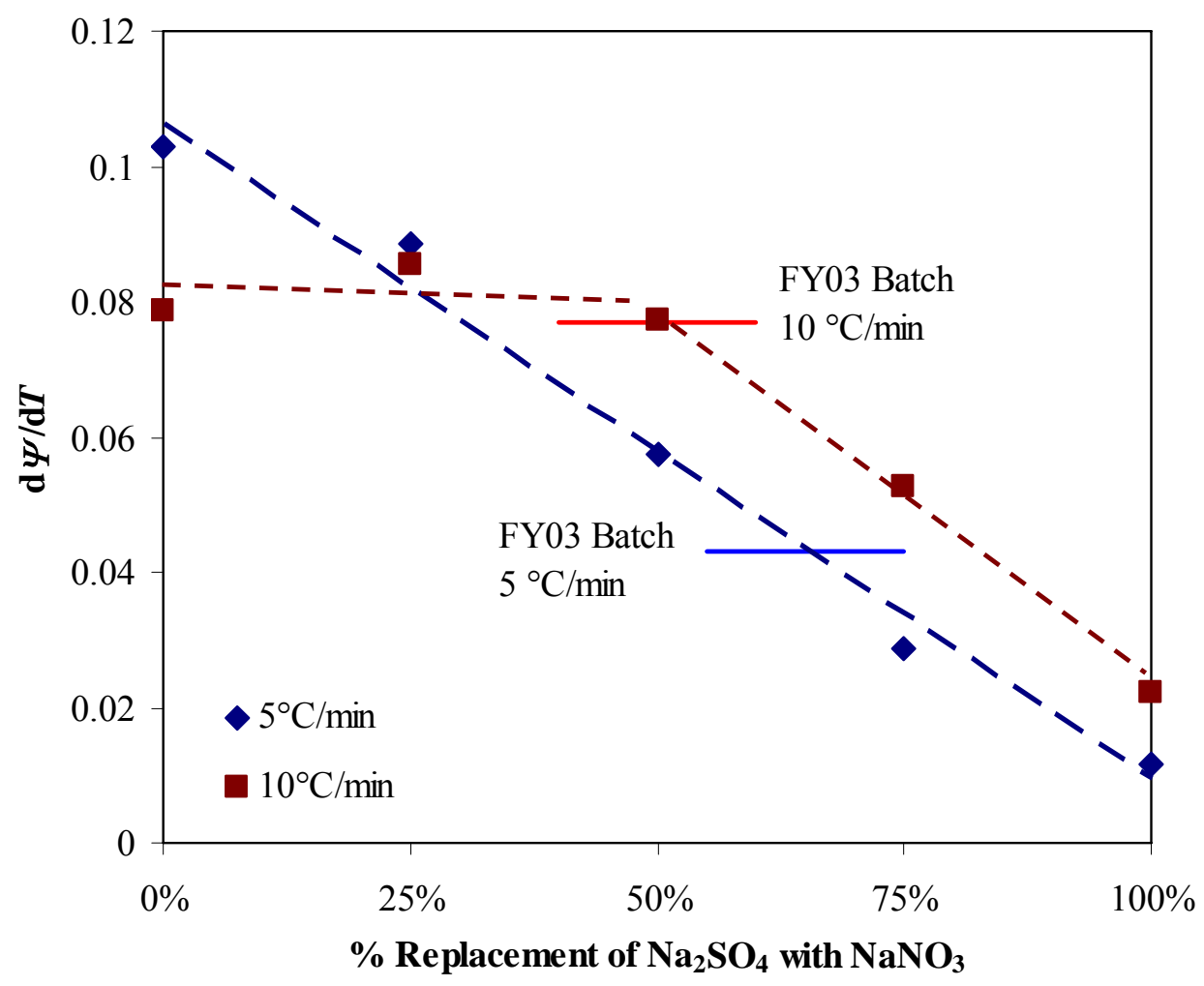

Figure 3.24. $\mathrm{d} \psi / \mathrm{d} T$ Versus Percent Replacement of $\mathrm{Na}_{2} \mathrm{SO}_{4}$ with $\mathrm{NaNO}_{3}$

Table 3.3. Target $\mathrm{SO}_{3}$ Concentration in FY03 and FY05 Batches

\begin{tabular}{|c|c|c|c|c|c|c||}
\hline & \multicolumn{5}{|c||}{ FY05 Batch } & \multirow{2}{*}{ FY03 } \\
Batch \\
\hline Replacement of $\mathrm{Na}_{2} \mathrm{SO}_{4}$ & $0 \%$ & $25 \%$ & $50 \%$ & $75 \%$ & $100 \%$ & 0.17 \\
\hline Total target $\mathrm{SO}_{3} \mathrm{wt} \%$ & 0.25 & 0.22 & 0.15 & 0.09 & 0.03 & 0.17 \\
\hline $\mathrm{SO}_{3} \mathrm{wt} \%$ from $\mathrm{Na}_{2} \mathrm{SO}_{4}$ & 0.22 & 0.19 & 0.12 & 0.06 & 0.00 & 0.085 \\
\hline
\end{tabular}




\subsection{Conclusions}

Reruns of foaming tests with the E-glass batch used in a previous study (Kim et al. 2004) and designated as FY03 batch, resulted in the same trend as observed in a previous study: the foaming extent, measured by maximum $\psi$ and $\mathrm{d} \psi / \mathrm{d} T$, increased nearly linearly with the heating rate and no foam was produced when $\mathrm{CO}_{2}+55 \% \mathrm{H}_{2} \mathrm{O}$ atmosphere was introduced at $300^{\circ} \mathrm{C}$. The results of sulfate analyses retained in the glass after foaming tests confirmed that the lack of foaming in the test with $\mathrm{CO}_{2}+55 \% \mathrm{H}_{2} \mathrm{O}$ atmosphere introduced at $300^{\circ} \mathrm{C}$ was caused by a loss of sulfate at $T<1250^{\circ} \mathrm{C}$ because of higher water content at the early stages of melting.

The tests with FY05 baseline batch containing more sulfate than the FY03 batch produced substantially higher foam and did not show noticeable effect of the heating rate on the foaming extent. Replacing quicklime with limestone showed a tendency to decrease foaming, possibly caused by increased sulfate loss during early stages of melting in the batch with limestone. The batches where $\mathrm{Na}_{2} \mathrm{SO}_{4}$ was replaced with $\mathrm{NaNO}_{3}, \mathrm{NaNO}_{3}+\mathrm{CeO}_{2}$, or $\mathrm{CeO}_{2}$, produced only very limited foaming regardless of the replacing components. As expected, the foaming extent decreased as the replacement of sulfate by $\mathrm{NaNO}_{3}$ increased and thus the sulfate content in the batch decreased. The results of the present study with FY05 suggest that foaming can be reduced by using limestone over quicklime and by decreasing the sulfate addition to a minimum required for refining. 


\subsection{References}

Fedorov AG and L Pilon. 2002. "Glass Foams: Formation, Transport Properties, Heat, Mass, and Radiation Transfer.” Journal of Non-Crystalline Solids, 311(2):154-173.

Hrma P, and D Kim. 1994. "Sulfate Mass Balance and Foaming Threshold in a Soda-Lime Glass." Glass Technol. 35(3):128-134.

Kappel J, R Conradt, and H Scholze. 1987. "Foaming Behavior on Glass Melts." Glastech. Ber. 60(6): 189-201.

Kim D, and P Hrma. 1991. "Foaming in Glass Melts Produced by Sodium Sulfate Decomposition under Isothermal Conditions.” J. Am. Ceram. Soc. 74(3):551-555.

Kim D, and P Hrma. 1992. "Foaming in Glass Melts Produced by Sodium Sulfate Decomposition under Ramp Heating Conditions.” J. Am. Ceram. Soc. 75(11):2959-63.

Kim D, P Hrma, BC Dutton, and L Pilon. 2004. Foaming of E-Glass (Report for G Plus Project for PPG. PNNL-14625, Pacific Northwest National Laboratory, Richland, WA.

Kokubu Y, J Chiba, T Okamura. 1977. "The Behavior of Sodium Sulfate during Glass Melting Process." pp. 147-54 in Proceedings of the $11^{\text {th }}$ International Congress on Glass, Vol. IV. CSTV DUM Techiky, Prague, Czechoslovakia.

Laimböck PR. 1998. "Foaming of glass melts.” University of Technology, Eindhoven, Ph.D. Thesis. 